\title{
Increased expression of inhibitor of apoptosis proteins, survivin and XIAP, in non-small cell lung carcinoma
}

\author{
EVZEN KREPELA $^{1}$, PETRA DANKOVA ${ }^{1}$, ERIKA MORAVCIKOVA ${ }^{1}$ ANNA KREPELOVA $^{5}$, JAN PROCHAZKA ${ }^{1}$, \\ JAN CERMAK $^{2}$, JAN SCHÜTZNER ${ }^{6}$, PETR ZATLOUKAL ${ }^{3}$ and KAMILA BENKOVA ${ }^{4}$ \\ ${ }^{1}$ Laboratories of Molecular and Cell Biology, ${ }^{2}$ Division of Surgery and ${ }^{3}$ Division of Pneumology, Department of \\ Pneumology and Thoracic Surgery, ${ }^{4}$ Department of Pathology, University Hospital Bulovka, Prague; \\ ${ }^{5}$ Institute of Biology and Medical Genetics of the Second Faculty of Medicine, and ${ }^{6}$ Third Department of \\ Surgery of the First Faculty of Medicine, University Hospital Motol, Prague, Czech Republic
}

Received June 5, 2009; Accepted August 7, 2009

DOI: 10.3892/ijo_00000464

\begin{abstract}
Members of the inhibitor of apoptosis protein (IAP) family, survivin and X-chromosome-linked IAP (XIAP), contribute to apoptosis resistance of cancer cells, and an increase in their expression may elevate the apoptotic threshold of malignant tumours during their growth and progression. In the present study, we investigated the expression status of survivin and its interactants hepatitis B $\mathrm{X}$-interacting protein (HBXIP) and XIAP in non-small cell lung carcinoma (NSCLC) cell lines and NSCLC tumours and matched lungs from surgically treated patients in relation to their clinicopathological data. The expression of survivin, HBXIP and XIAP mRNAs was quantitated by real-time RT-PCR. The expression of survivin and XIAP proteins was analysed by Western blotting and ELISA. Survivin mRNA and protein levels were highly upregulated in NSCLC cells and tissues as compared to the lungs. In fact, the levels of survivin mRNA and protein in the tumours were more than 10-fold higher in $96(64 \%)$ and $72(82 \%)$ of the 150 and 88 examined NSCLC patients, respectively. The expression of survivin mRNA was higher in squamous cell lung carcinomas than in lung adenocarcinomas (LACs; $\mathrm{P}=0.003$ ) and in less-differentiated tumours than in well-differentiated ones $(\mathrm{P}=0.007)$. The level of survivin protein was higher in stage IB and stage II+III tumours $(\mathrm{P}=0.049$ and $\mathrm{P}=0.044)$, than in stage IA tumours. The BIRC5 promoter polymorphism at nucleotide -31 did not influence the expression of survivin mRNA and protein in NSCLC cells and tumours. HBXIP mRNA was abundantly expressed in NSCLC cell lines and
\end{abstract}

Correspondence to: Dr Evzen Krepela, Department of Pneumology and Thoracic Surgery, University Hospital Bulovka, Budinova 2, 18081 Prague 8, Czech Republic

E-mail: krepelae@fnb.cz

Key words: non-small cell lung carcinoma, survivin, hepatitis B $\mathrm{X}$-interacting protein, $\mathrm{X}$-chromosome-linked inhibitor of apoptosis protein, expression, apoptosis
NSCLC tumours and lungs, while its level was comparable in the tumours and lungs. The expression of XIAP mRNA in NSCLC cell lines and NSCLC tumours and lungs was not significantly different. However, the expression of XIAP protein was higher in NSCLC tumours, particularly in LACs, as compared to the lungs $(\mathrm{P}=0.017$ and $\mathrm{P}=0.004)$. In conclusion, the overexpression of survivin in the majority of NSCLCs together with the abundant or upregulated expression of HBXIP and XIAP suggest that tumours are endowed with resistance against a variety of apoptosis-inducing conditions.

\section{Introduction}

The human inhibitor of apoptosis protein (IAP) family encompasses eight members: NAIP (BIRC1), cIAP1 (BIRC2), cIAP2 (BIRC3), XIAP (BIRC4), survivin (BIRC5), apollon (BIRC6), livin (BIRC7) and ILP-2 (BIRC8) $(1,2)$. These proteins participate in the regulation of a variety of cell functions including apoptosis, cell division, non-apoptotic signal transduction and copper homeostasis $(1,2)$. IAPs block apoptotic cell death primarily via mechanisms that repress the activation and activity of certain caspases and/or reduce their protein levels. These mechanisms involve prevention of the activation of procaspase-9 (3) and $-8(2,4)$, inhibition of the activity of caspase-9, -3 and -7 (5-9), and ubiquitination of active caspase-9, -3 and -7 to promote their proteasomal degradation (10-14). Moreover, various IAPs such as XIAP, cIAP1, cIAP2, apollon and livin can bind to the endogenous IAP-antagonists Smac (15) and Htra2 (16) and ubiquitinate them to facilitate their degradation by proteasomes (10,14,17-20). Besides their caspase-, Smac- and Htra2directed antiapoptotic activities, both cIAPs and XIAP are capable of activating the nuclear factor (NF)- $\mathrm{BB}$ signaling pathways and thereby generate a series of prosurvival responses in cancer cells as well as in vascular endothelial cells $(1,2,4,21-23)$.

Resistance to apoptosis contributes to cancerogenic transformation of cells and tumourigenesis as well as to malignant progression of tumours and lack of their responsiveness to non-surgical modes of therapy (24-26). Although the overexpression of multiple IAPs has been implicated in apoptosis 
resistance of human neoplasms (2,27-30), recent data indicate that high expression of both survivin and XIAP is particularly critical for apoptosis suppression in cancer cells derived from solid human tumours (31-36). Moreover, survivin and XIAP are also upregulated in angiogenic factoractivated endothelial cells of tumour microvasculature and protect them from endogenous and exogenous apoptotic stimuli (37-40).

Survivin and XIAP have been implicated as resistance factors in the drug- and radiation-induced apoptosis of nonsmall cell lung carcinoma (NSCLC) cells (41-45). Based on these data, there is a possibility that both survivin and XIAP may contribute to tumourigenesis and progression of NSCLCs due to their apoptosis suppression functions. Therefore, in the present study, we investigated the expression status of survivin and its antiapoptotic-function-promoting interactants hepatitis B X-interacting protein (HBXIP) and X-chromosome-linked IAP (XIAP) in NSCLC cell lines and different subtypes of NSCLC tumours and lungs from surgically treated patients in relation to clinicopathological data.

\section{Materials and methods}

Cell lines. The non-small cell lung carcinoma (NSCLC) cell lines were purchased from the following depositories: CALU-1, SKMES-1, A549, SKLU-1 and COR-L23 from the European Collection of Cell Cultures, Salisbury, UK; LXF-289, COLO-699 and LCLC-103H from the German Collection of Microorganisms and Cell Cultures, Braunschweig, Germany; NCI-H520 and NCI-H1299 from the American Type Culture Collection (ATCC), Rockville, MD, USA. The small cell lung carcinoma (SCLC) cell lines NCI-H69, NCI-H146, NCI-H209, NCI-H345, NCI-H378, NCI-H82 and NCI-H446 were purchased from ATCC. Media used for cell cultivation and their supplements were obtained from Sigma, St. Louis, MO, USA. The NSCLC cell lines were grown in a humidified atmosphere of air with $5 \% \mathrm{CO}_{2}$ at $37^{\circ} \mathrm{C}$ in Eagle's minimum essential medium supplemented with $5 \%$ foetal bovine serum, $26.2 \mathrm{mM} \mathrm{NaHCO}, 2 \mathrm{mM}$ $L$-glutamine, $1 \%$ of a stock solution of non-essential amino acids, $0.25 \mu \mathrm{M} \mathrm{Fe}\left(\mathrm{NO}_{3}\right)_{3}, 10 \mathrm{mg} / \mathrm{l}$ apotransferrin, and $10^{5} \mathrm{IU} / \mathrm{l}$ of penicillin-G and $100 \mathrm{mg} / \mathrm{l}$ of streptomycin. After reaching confluency, the cultivation medium was removed, and the attached cells were harvested by gentle scraping either into a lysis solution for the isolation of DNA and RNA or into the $\mathrm{Ca}^{2+}$ - and $\mathrm{Mg}^{2+}$-free Hanks' balanced salt solution for preparation of protein extracts (described below). The SCLC cell lines were cultured in a humidified atmosphere of air with $5 \% \mathrm{CO}_{2}$ at $37^{\circ} \mathrm{C}$ in RPMI-1640 medium supplemented with $10 \%$ foetal bovine serum, $23.8 \mathrm{mM} \mathrm{NaHCO}, 2 \mathrm{mM}$ $L$-glutamine, and $10^{5} \mathrm{IU} / 1$ of penicillin-G and $100 \mathrm{mg} / \mathrm{l}$ of streptomycin. The cells were harvested by centrifugation at $240 \mathrm{x} \mathrm{g}$ and $4^{\circ} \mathrm{C}$ for $10 \mathrm{~min}$.

Patients and tissues. The patients $(\mathrm{n}=150)$ (median age, 62 years; range, 39-78 years; 110 men and 40 women; 130 smokers and 20 non-smokers) entering the study had not received radiotherapy or chemotherapy before surgery for lung cancer. The surgical treatment applied to the patients included lung lobectomy, bilobectomy or pneumonectomy, and regional lymph node dissection. The histopathological classification of lung tumours was carried out according to the World Health Organization criteria (46), and the following NSCLC types were included in the present study: squamous cell lung carcinoma (SQCLC, $n=69$ ), lung adenocarcinoma (LAC, $n=56)$, SQCLC+LAC mixed-type tumours $(n=3)$, large-cell lung carcinoma (LCLC, $n=7$ ), sarcomatoid lung carcinoma (SLC, $n=4)$ and undifferentiated lung carcinoma (UNDIF, $\mathrm{n}=11$ ). Tumour staging was performed according to the International pTNM Staging System (47). Written informed consent was obtained from each patient before entry into the study. The study was approved by the local institutional ethics committee.

Tissue samples (190-240 mg, wet mass) of primary lung tumours and non-tumourous lungs were excised from the resected lung lobe or lung immediately after surgery. Tumour samples were taken from a non-necrotic part of tumour, and lung samples were excised from the lung parenchyma at a site located as distantly as possible from the tumour location. All tissue samples were snap-frozen in liquid nitrogen and stored at $-78^{\circ} \mathrm{C}$ until isolation of DNA and total RNA and total protein extraction.

Isolation and quantification of DNA. Genomic DNA was isolated from cultured NSCLC cell lines and NSCLC tissue samples using the Puregene DNA Isolation Kit (cat. no. D-7000a; Gentra Systems, Minneapolis, MI, USA) according to the manufacturer's guidelines. The concentration of DNA was determined by spectrophotometry at $260 \mathrm{~nm}$ in $10 \mathrm{mM}$ Tris/HCl buffer, $\mathrm{pH}$ 7.5. Preparations of DNA in the Hydration Solution (a Tris/EDTA buffer) were stored in small aliquots at $-78^{\circ} \mathrm{C}$ until analysis.

DNA sequencing. Genotyping of the survivin gene (BIRC5) promoter for the polymorphism at nucleotide (NT) -31 in NSCLC cell lines and NSCLC tissues was performed using direct DNA sequencing, in both forward and reverse directions, of purified PCR products after specific PCR amplification of a survivin promoter region from NTs -510 to +40 using genomic DNA as the template. DNA amplification was carried out in a 30- $\mu 1$ PCR reaction containing $10 \mathrm{mM}$ Tris/HCl buffer, $\mathrm{pH} 8.8,50 \mathrm{mM} \mathrm{KCl}, 0.08$ v/v\% Nonidet NP40, $200 \mathrm{nM}$ of each dGTP, dCTP, dATP and dTTP, $1 \mathrm{mM}$ $\mathrm{MgCl}_{2}, 15$ pmol of the amplification primers 5'-CAATCTC AGCTCACTGCACCCTCT-3' (forward) and 5'-GAAAG GGCTGCCAGGCAGGGGGCAA-3' (reverse) (48), $100 \mathrm{ng}$ of genomic DNA, and 1 unit of Taq DNA Polymerase (Fermentas, Vilnius, Lithuania). The amplification consisted of 32 cycles of denaturation at $95^{\circ} \mathrm{C}$ for $1 \mathrm{~min}$, annealing at $58^{\circ} \mathrm{C}$ for $1 \mathrm{~min}$, and extension at $72^{\circ} \mathrm{C}$ for $2 \mathrm{~min}$, followed by a final extension at $72^{\circ} \mathrm{C}$ for $7 \mathrm{~min}$. The PCR products were purified using the SureClean PCR purification kit (Bioline, London, UK) according to the recommendations of the supplier. DNA sequencing was carried out using the purified PCR product, BigDye Terminator v3.1 Cycle Sequencing Kit (Applied Biosystems), and the nested sequencing primers 5'-AGCTCACTGCACCCTCTGCC-3' or 5'-CTGCCAGG CAGGGGGCAACG-3'. Sequence analysis was performed on the 3100-Avant Genetic Analyzer (Applied Biosystems, Foster City, CA, USA). 
Table I. Primers and TaqMan probes used for real-time RT-PCR quantitation of expression of the investigated transcripts.

\begin{tabular}{|c|c|c|c|c|}
\hline Transcript & $\begin{array}{c}\text { GeneBank } \\
\text { accession no. }\end{array}$ & & Sequences of primers and TaqMan probe & $\begin{array}{c}\text { Final } \\
\text { concentration }\end{array}$ \\
\hline \multirow[t]{3}{*}{ Survivin } & NM_001168 & Forward primer: & 5'-GACGACCCCATAGAGGAACATA-3' & $400 \mathrm{nM}$ \\
\hline & & Reverse primer: & 5'-TTTCCTTTGCAATTTTGTTCTTG-3' & $400 \mathrm{nM}$ \\
\hline & & TaqMan probe: & 5'-(6-FAM) CCGGTTGCGCTTTCCTTTCTGTCA (TAMRA)-3' & $200 \mathrm{nM}$ \\
\hline \multirow[t]{3}{*}{ HBXIP } & NM_006402 & Forward primer: & 5'-AGCACTTGGAAGACACAATGAAG-3' & $400 \mathrm{nM}$ \\
\hline & & Reverse primer: & 5'-GTTTCTGGATCATAATGTTCCCAT-3' & $400 \mathrm{nM}$ \\
\hline & & TaqMan probe: & 5'-(6-FAM) CCGCGGGACCCTGTCAGATGA (TAMRA)-3' & $200 \mathrm{nM}$ \\
\hline \multirow[t]{3}{*}{ XIAP } & $\mathrm{U} 45880$ & Forward primer: & 5'-TCCAGAATGGTCAGTACAAAGTTG-3' & $200 \mathrm{nM}$ \\
\hline & & Reverse primer: & 5'-TTTGTTGAATTTGGGAAATTCCT-3' & $200 \mathrm{nM}$ \\
\hline & & TaqMan probe: & 5'-(6-FAM) CACTTCGAATATTAAGATTCCGGCCCA (TAMRA)-3' & $200 \mathrm{nM}$ \\
\hline \multirow[t]{3}{*}{ B-actin } & NM_001101 & Forward primer: & 5'-CTGGCACCCAGCACAATG-3' & $200 \mathrm{nM}$ \\
\hline & & Reverse primer: & 5'-GGGCCGGACTCGTCATAC-3' & $200 \mathrm{nM}$ \\
\hline & & TaqMan probe: & 5'-(VIC) AGCCGCCGATCCACACGGAGT (TAMRA)-3' & $200 \mathrm{nM}$ \\
\hline
\end{tabular}

Isolation and quantification of total RNA. Total RNA was isolated from tumour and lung tissue samples and from cultured NSCLC and SCLC cell lines using the Trizol Reagent (Invitrogen, Paisley, UK) according to the manufacturer's instructions. Spectrophotometric analysis, which was carried out in $10 \mathrm{mM}$ Tris/HCl buffer, $\mathrm{pH} 7.5$, revealed that all samples of total RNA had an $\mathrm{A}_{260 \mathrm{~nm}} / \mathrm{A}_{280 \mathrm{~nm}}$ ratio $>1.8$. The concentration of total RNA was determined by fluorometry using the RiboGreen RNA Quantitation Kit (Molecular Probes, Eugene, OR, USA) according to the manufacturer's protocol. The preparations of total RNA in RNase-free water (ICN Biomedicals, Irvine, CA, USA) were stored in small aliquots at $-78^{\circ} \mathrm{C}$ until analysis.

Real-time RT-PCR analysis. The sequences and final concentrations of the oligonucleotide primers and probes used in real-time RT-PCR assays of expression of the investigated transcripts are indicated in Table I. The concentrations of primers and TaqMan probes adopted for real-time RT-PCR quantitation of each studied transcript were determined in optimization experiments. The primers and probes were designed with the program Primer Express (Applied Biosystems) and were synthesized at Proligo (Paris, France) and Applied Biosystems (Warrington, Cheshire, UK), respectively.

The expression of survivin mRNA and HBXIP mRNA was quantitated by a two-step real-time RT-PCR assay as follows. In the first step, $2 \mu \mathrm{g}$ of total RNA was reverse transcribed in a total volume of $20 \mu \mathrm{l}$ of $50 \mathrm{mM}$ Tris/acetate buffer, $\mathrm{pH} 8.4$, containing $75 \mathrm{mM}$ of potassium acetate, $8 \mathrm{mM}$ of magnesium acetate, $500 \mathrm{nM}$ of the gene-specific reverse primer (Table I), $200 \mathrm{nM}$ of each dGTP, dCTP, dATP and dTTP, $5 \mathrm{mM}$ dithiothreitol, 40 units of RNase inhibitor RNAseOUT (Invitrogen) and 15 units of ThermoScript Reverse Transcriptase (Invitrogen). The RT reaction was carried out at $58^{\circ} \mathrm{C}$ for $30 \mathrm{~min}$ and was terminated by heating at $85^{\circ} \mathrm{C}$ for $10 \mathrm{~min}$. The resulting RT mixes were stored at $-25^{\circ} \mathrm{C}$ until PCR analysis. The PCR step was carried out in a total volume of $50 \mu \mathrm{l}$ of $20 \mathrm{mM}$ Tris/ $\mathrm{HCl}$ buffer, $\mathrm{pH} 8.4$, containing $50 \mathrm{mM}$ of $\mathrm{KCl}, 1.85 \mathrm{mM}$ of $\mathrm{MgCl}_{2}, 220 \mathrm{nM}$ of each $\mathrm{dGTP}, \mathrm{dCTP}, \mathrm{dATP}$ and dTTP, the indicated concentrations of gene-specific forward and reverse primers and TaqMan probe (Table I), 2 units of Platinum Taq DNA polymerase (Invitrogen), and $2 \mu \mathrm{l}$ of the RT mix (representing an equivalent of an input of $200 \mathrm{ng}$ of total RNA). The PCR amplification included a hot start at $95^{\circ} \mathrm{C}$ for $3 \mathrm{~min}$ and 45 cycles of denaturation at $95^{\circ} \mathrm{C}$ for $15 \mathrm{sec}$ and of annealing/ extension at $58^{\circ} \mathrm{C}$ for $1 \mathrm{~min}$.

The expression of XIAP mRNA was quantitated by a coupled real-time RT-PCR assay as follows. The RT-PCR reaction mixtures had a total volume of $50 \mu \mathrm{l}$ and contained $25 \mu \mathrm{l}$ of ThermoScript Reaction Mix (a buffer with $3 \mathrm{mM}$ $\mathrm{MgSO}_{4}$ and $200 \mathrm{nM}$ of each dGTP, dCTP, dATP and dTTP) and $1 \mu 1$ of ThermoScript Plus Reverse Transcriptase/ Platinum Taq DNA Polymerase Mix (both Mixes were from Platinum Quantitative RT-PCR ThermoScript One-Step System, Invitrogen), the indicated concentrations of genespecific forward and reverse primers and TaqMan probe (Table I), 40 units of RNaseOUT (Invitrogen), and an input of $200 \mathrm{ng}$ of total RNA.

The expression of $\beta$-actin mRNA (an internal reference transcript) was quantitated in parallel to the indicated target transcripts either by the two-step or by the coupled real-time RT-PCR assay as described above. The respective genespecific forward and reverse primers and TaqMan probe and their concentrations in the PCR assays were as indicated in Table I.

The real-time RT-PCR assays were run in triplicate or duplicate in MicroAmp Optical 96-well Reaction Plates on the ABI PRISM 7700 Sequence Detection System (SeDeS) operated from within the SeDeS software (all from Applied Biosystems). The threshold cycle $\left(\mathrm{C}_{\mathrm{T}}\right)$ values of the amplification reactions, represented by the plots of backgroundsubtracted fluorescence intensity $(\Delta \mathrm{FI})$ of the reporter dye (6-FAM or VIC) against PCR cycle number, were determined with the SeDeS software. The tumour/lung ratio of the $\beta$-actin mRNA-normalised target transcript expression was calculated by means of the $2^{-\Delta \Delta \mathrm{C}_{\mathrm{T}}}$ method (49), and the 
statistical difference of the $\beta$-actin mRNA-normalised target transcript expression in tumours and lungs was calculated from the linearized $\Delta \mathrm{C}_{\mathrm{T}}$ data (i.e. $2^{-\Delta \mathrm{C} T}$ ) (50).

Preparation of protein extracts and total protein determination. NSCLC cell lines harvested by scraping into the $\mathrm{Ca}^{2+}$ - and $\mathrm{Mg}^{2+}$-free Hanks' balanced salt solution were pelleted by centrifugation at $240 \mathrm{x}$ g and $4^{\circ} \mathrm{C}$ for $10 \mathrm{~min}$. The pellets were disrupted in lysis buffers by sonication. For the analysis of survivin protein expression, the lysis buffer was $0.5 \%$ Triton $\mathrm{X}-100,0.005 \%$ Tween-20 and $6 \mathrm{M}$ urea in phosphate-buffered saline, $\mathrm{pH}$ 7.2-7.4, containing a mixture of proteinase inhibitors including $1 \mathrm{mM} \mathrm{Na}{ }_{2}$ EDTA, $50 \mu \mathrm{M}$ E-64, $200 \mu \mathrm{M}$ AEBSF and $25 \mu \mathrm{M}$ pepstatin. For the analysis of XIAP protein expression, the lysis buffer was the same except urea. Frozen tissue samples were homogenized on ice in $800 \mu \mathrm{l}$ of the mentioned lysis buffers using the UltraTurrax T25 homogenizer fitted with the probe S25N-8G (Janke and Kunkel, Staufen, Germany). Ten 5-sec probe bursts at 24,000 rpm were applied. The homogenates were centrifuged at $40,000 \times \mathrm{g}$ and $4^{\circ} \mathrm{C}$ for $30 \mathrm{~min}$, and the collected supernatants, i.e. extracts, were divided into small aliquots and stored at $-78^{\circ} \mathrm{C}$ until analysis.

Total protein concentration in the extracts was determined by the bicinchoninic acid assay using bovine serum albumin as a standard (51).

Immunoblotting analysis. The expression of survivin and XIAP proteins in NSCLC cells was investigated using denaturing SDS-polyacrylamide gel electrophoresis and immunoblotting with specific antibodies. The electrophoretic separation of extracted proteins (100 $\mu \mathrm{g}$ of per lane) was carried out in $16.5 \% \mathrm{~T} / 3 \% \mathrm{C}$ and $12.5 \% \mathrm{~T} / 3 \% \mathrm{C}$ polyacrylamide gels, respectively, using the Tris-Tricine-SDS buffer system (52). The Precision Plus Protein Prestained Standards (BioRad, Hercules, CA, USA) were run in parallel to extracted proteins which were preboiled for $5 \mathrm{~min}$ in $50 \mathrm{mM}$ Tris/ $\mathrm{HCl}$ buffer, $\mathrm{pH} 7.4$, containing $2.5 \%$ SDS, $100 \mathrm{mM}$ dithiothreitol, $5 \%$ glycerol and $0.01 \%$ Serva Blue G. The separated proteins were electrotransferred onto sheets of Hybond P membrane (Amersham Pharmacia Biotech, Little Chalfont, UK) using a transfer buffer $48 \mathrm{mM}$ Tris, $39 \mathrm{mM}$ glycine, $1.3 \mathrm{mM}$ SDS, $20 \mathrm{v} / \mathrm{v} \%$ methanol, $\mathrm{pH}$ 9.2. Survivin and XIAP proteins were visualised on the membrane by an immunodetecting procedure coupled to an enhanced chemiluminescence generating system. The specific primary antibodies used were anti-survivin mouse monoclonal $\mathrm{IgG}_{2 \mathrm{a}}$ (Santa Cruz Biotechnology, Santa Cruz, CA, USA; cat. no. sc-17779) and anti-XIAP rabbit polyclonal IgG (R\&D Systems, Minneapolis, MN, USA; cat. no. RD-AF822). The secondary antibodies used were goat anti-mouse $\operatorname{IgG}_{2 \mathrm{a}^{-}}$ horseradish peroxidase (HRP) conjugate (Santa Cruz Biotechnology) and goat anti-rabbit IgG-HRP peroxidase conjugate (Sigma). The immunoblotting procedure was carried out at room temperature with the following treatment steps: blocking with 5\% Blotting Grade Blocker (BGB; BioRad) and $1 \%$ bovine serum albumin (BSA) in PBST buffer $\left(20 \mathrm{mM} \mathrm{NaH} \mathrm{PO}_{4} / 80 \mathrm{mM} \mathrm{Na} \mathrm{HPO}_{4}, 100 \mathrm{mM} \mathrm{NaCl}\right.$, $0.1 \%$ Tween-20, $\mathrm{pH} 7.4$ ) for $1 \mathrm{~h}$, incubation with the primary antibody (at $1 \mu \mathrm{g} / \mathrm{ml}$ in $1 \% \mathrm{BGB}$ and $0.2 \%$ BSA in PBST buffer) for $2 \mathrm{~h}$, extensive washing with PBST buffer, incubation with the secondary HRP-conjugated antibody (at a dilution of $1: 10000$ in $1 \% \mathrm{BGB}$ and $0.2 \% \mathrm{BSA}$ in PBST buffer) for $1 \mathrm{~h}$, extensive washing with PBST buffer, incubation with the ECL Plus Reagent (Amersham Pharmacia Biotech) for $5 \mathrm{~min}$, and capture of the chemiluminescence signal on BioMax Light-1 film (Eastman Kodak, Rochester, NY, USA). The net intensity of survivin and XIAP protein bands in the film immunograms was evaluated with the 1D Image Analysis Software (Eastman Kodak) as described previously (53).

Determination of survivin and XIAP proteins. The levels of survivin and XIAP proteins in cell and tissue extracts were measured by chromogenic sandwich enzyme-linked immunosorbent assays (ELISAs) using Human Survivin ELISA DuoSet IC (cat. no. DYC647) and Human XIAP ELISA DuoSet IC (cat. no. DYC822) kits (R\&D Systems) according to the manufacturer's instructions. For ELISA of survivin protein, 2.5 and $5 \mu \mathrm{g}, 12.5$ and $25 \mu \mathrm{g}$, and 75 and $150 \mu \mathrm{g}$ of total extracted protein per microtiter plate well were routinely used in NSCLC cell lines, NSCLC tissues and lungs, respectively. For ELISA of XIAP protein, 5 and $10 \mu \mathrm{g}$ of total extracted protein per microtiter plate well were routinely used in NSCLC cell lines and tissues as well as in lungs. The intraassay coefficients of variation for ELISAs of low and high concentration of survivin and XIAP in extract samples were 3.1 and $4.9 \%$, and 2.5 and $4.6 \%$, respectively.

Statistical analysis. Statistical calculations were carried out with the programs SigmaStat (Systat Software, Point Richmond, CA, USA) and Stat200 (Biosoft, Cambridge, UK). A two-sided P-value $<0.05$ was considered as a statistically significant difference.

\section{Results}

To analyse the expression status of survivin, HBXIP and XIAP mRNAs in NSCLC cell lines and NSCLC tissues and lungs we quantitated the level of these transcripts and of $\beta$-actin mRNA by means of real-time RT-PCR. A set of PCR amplification plots which is shown in Fig. 1 illustrates overexpression of survivin mRNA in NSCLC tissues as compared to matched lungs and equal or comparable expression of HBXIP and XIAP mRNAs and B-actin mRNA in tumourlung matched pairs. Using the two-step real-time RT-PCR assay, there was no significant difference between the expression levels of $B$-actin mRNA ( $2^{-\mathrm{C}_{\mathrm{T}}}$ data) in the investigated NSCLC and SCLC cell lines ( $\mathrm{P}=0.66$, MannWhitney test) and in NSCLC tissues of different histopathological types and matched lungs ( $P>0.19$; MannWhitney test). With the coupled real-time RT-PCR assay, the expression of B-actin mRNA in NSCLC and SCLC cell lines was not significantly different $(\mathrm{P}=0.22$, Mann-Whitney test), but it was slightly and significantly higher in SQCLC and LAC tissues as compared to matched lungs $\left(\mathrm{P}=4.5 \times 10^{-4}\right.$ and $\mathrm{P}=4.1 \times 10^{-4}$, respectively, Mann-Whitney test).

Survivin (BIRC5) and XIAP (BIRC4) genes were strongly expressed in the studied NSCLC cell lines at both the mRNA and protein levels, and this expression showed a significant 


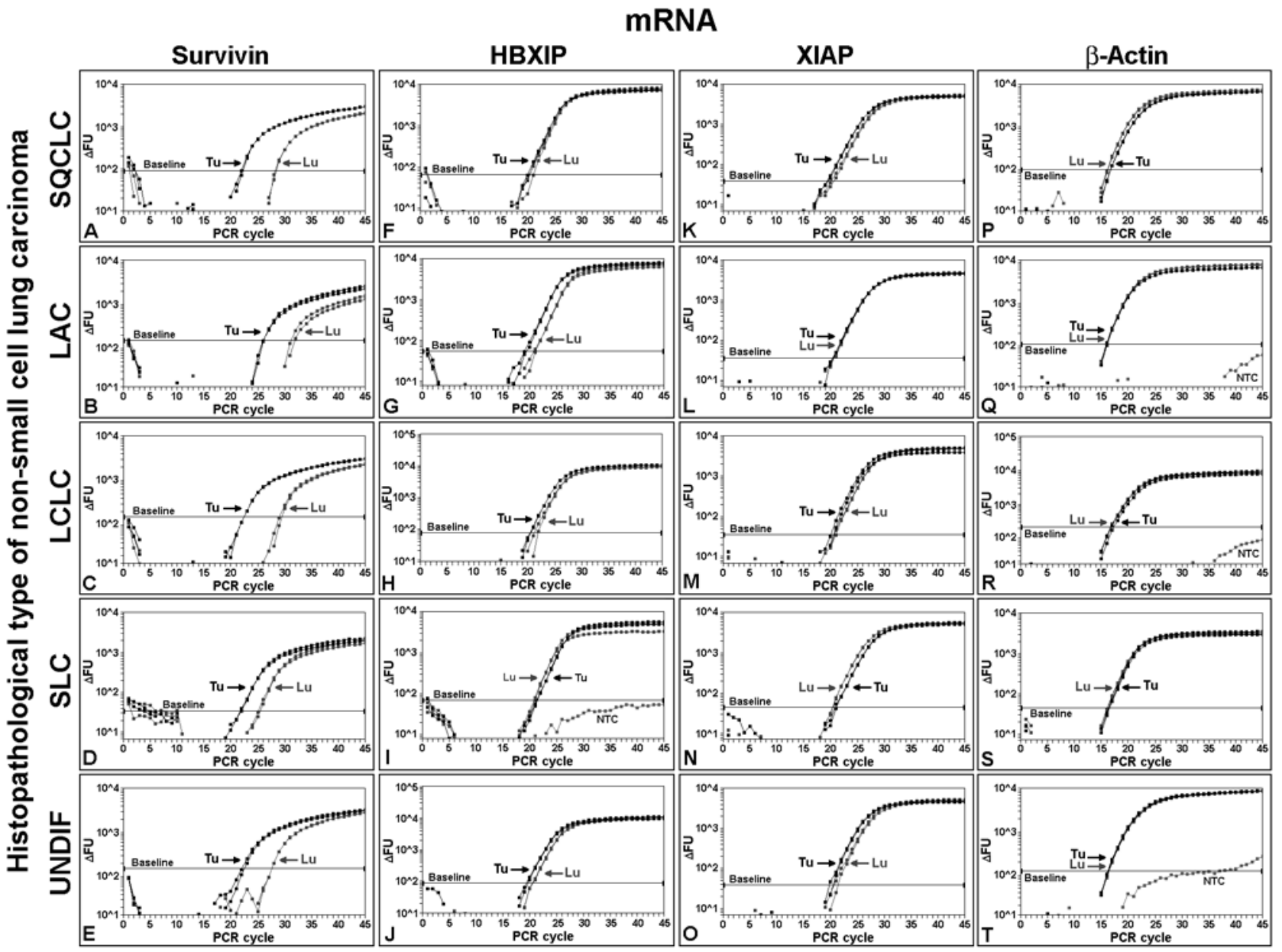

Figure 1. Real-time RT-PCR quantitation of expression of survivin, HBXIP, XIAP and B-actin mRNAs in non-small cell lung carcinoma tissues and matched lungs. The set of PCR amplification plots, representing the two-step (A-E, F-J and P-T) and the coupled (K-O) real-time RT-PCR assays with an input of 200 ng of total RNA and running in duplicate, shows the expression of survivin, HBXIP, XIAP and B-actin mRNAs in five tumour (Tu)-lung (Lu) matched pairs. The tumours were: squamous cell lung carcinoma (SQCLC), lung adenocarcinoma (LAC), large-cell lung carcinoma (LCLC), sarcomatoid lung carcinoma (SLC), and undifferentiated lung carcinoma (UNDIF). NTC, no template control. $\triangle \mathrm{FU}$, background-subtracted fluorescence intensity (in arbitrary units) of the released reporter dye (6-FAM or VIC).

positive correlation, respectively (Fig. 2). There was no obvious relationship between the genotype at NT -31 in BIRC5 promoter and the expression of survivin mRNA and protein in the studied NSCLC cell lines (Fig. 2A and B). The level of survivin mRNA, but not of XIAP mRNA, was significantly lower in NSCLC cell lines as compared to SCLC cell lines (Fig. 3). The latter findings confirm data previously reported for the expression of survivin and XIAP mRNAs in panels of different NSCLC and SCLC cell lines $(54,55)$.

The expression of survivin mRNA was substantially higher in NSCLC tissues of different histopathological types as compared to matched lungs (Table II). In fact, in 96 (64\%) of the 150 examined NSCLC patients, the tumours had a $>10$-fold higher level of survivin mRNA. Concerning the histopathological types of NSCLC, the expression of survivin mRNA in LACs was significantly lower as compared to SQCLCs, LCLCs and UNDIFs (Table II). The expression of survivin protein was also highly upregulated in NSCLC tissues as compared to matched lungs (Table III), while the level of survivin protein in the tumours was $>10$-fold higher in $72(82 \%)$ of the 88 examined NSCLC patients. The expression of survivin mRNA and protein showed a close positive correlation in NSCLC tissues but not in the lungs (Fig. 4). The expression of both survivin mRNA and protein in NSCLC tissues was significantly lower as compared to the studied NSCLC cell lines $\left(\mathrm{P}=7.9 \times 10^{-7}\right.$ and $\mathrm{P}=6.4 \times 10^{-5}$, respectively; Mann-Whitney test).

The BIRC5 promoter polymorphism at NT -31 had no significant impact on the expression of survivin mRNA and protein in NSCLC tissues (Fig. 5). The expression of survivin mRNA, but not of protein, reached a significantly higher level in the tumours of men than women, in the tumours of smokers than non-smokers, and in the less-differentiated tumours (Table IV). On the other hand, the expression of survivin protein, but not of mRNA, was significantly higher in stage IB tumours as well as in higher stage tumours as compared to stage IA tumours (Table IV). When SQCLCs and LACs were considered separately, the expression of survivin mRNA remained significantly higher in the lessdifferentiated tumours $(\mathrm{P}=0.035$ and $\mathrm{P}=0.008$, respectively; Mann-Whitney test), but it became statistically insignificantly different in the tumours of men and women and the tumours 
A

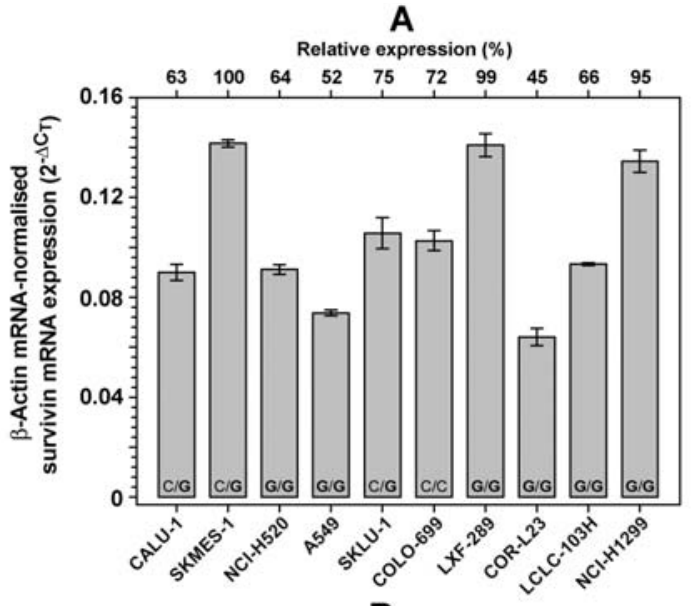

B

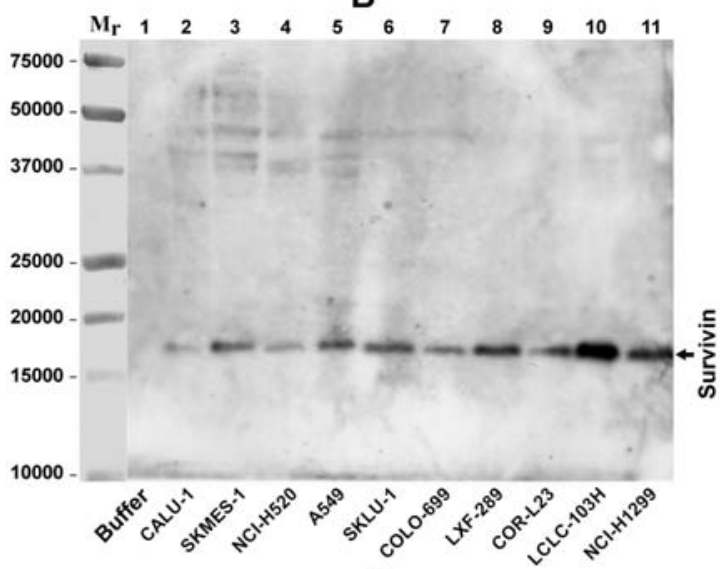

C

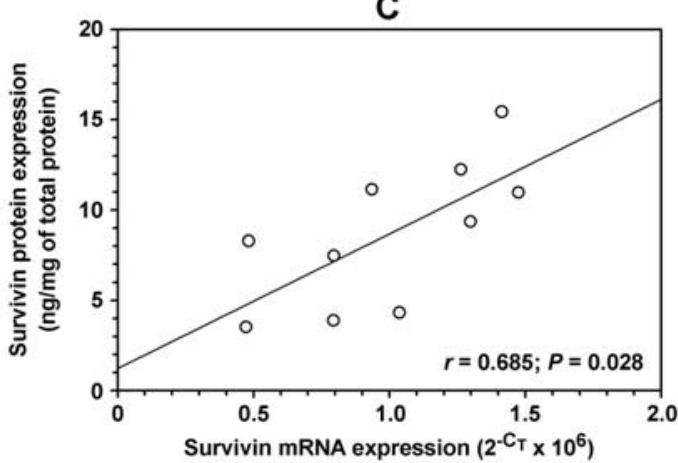

D

Relative expression (\%)

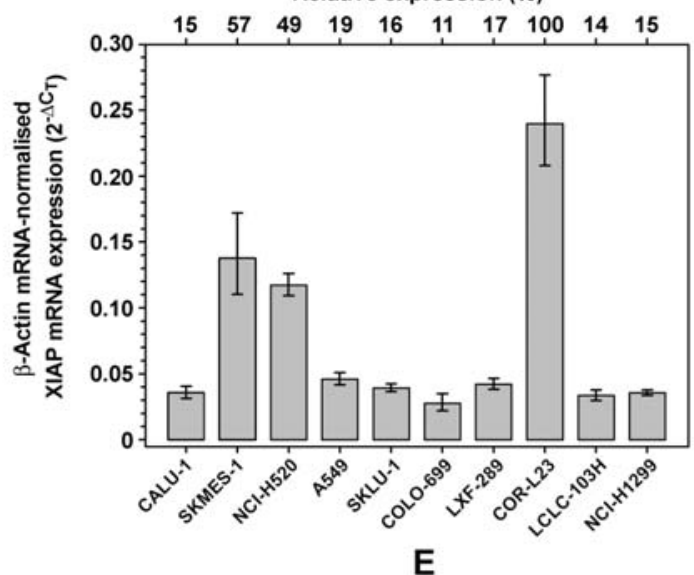

E

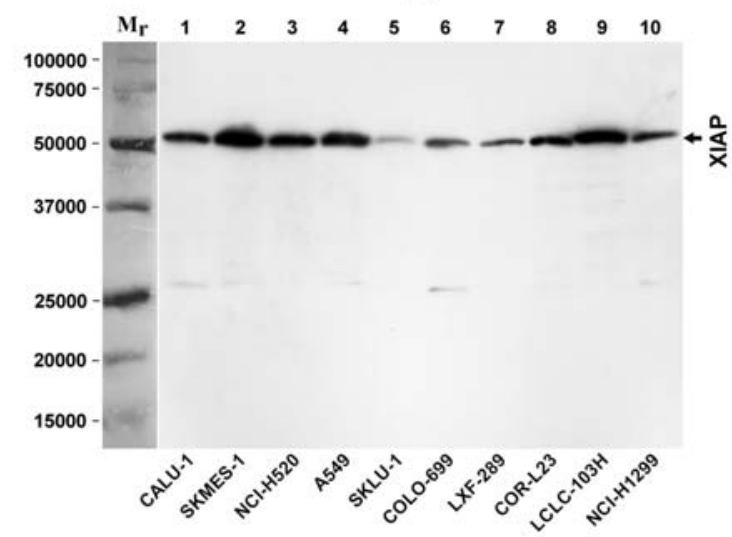

$\mathbf{F}$

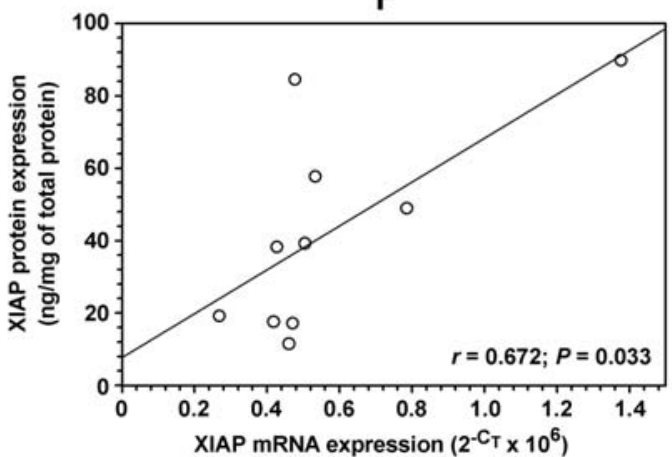

Figure 2. Analysis of survivin and XIAP expression in non-small cell lung carcinoma cell lines. (A and D) Expression of survivin and XIAP mRNAs in the tumour cell lines as quantitated by real-time RT-PCR. Data are represented as the mean \pm standard error of the mean of three independent experiments. At the bottom of each column, the genotype at nucleotide -31 in the survivin gene (BIRC5) promoter is shown. (B and E) Expression of survivin and XIAP proteins in the tumour cell lines as analysed by SDS-PAGE and immunoblotting. (C and F) Correlation analysis of mRNA and protein expression for survivin and XIAP, respectively, in the tumour cell lines. Pearson linear correlation coefficients $r$ and their P-value are indicated.
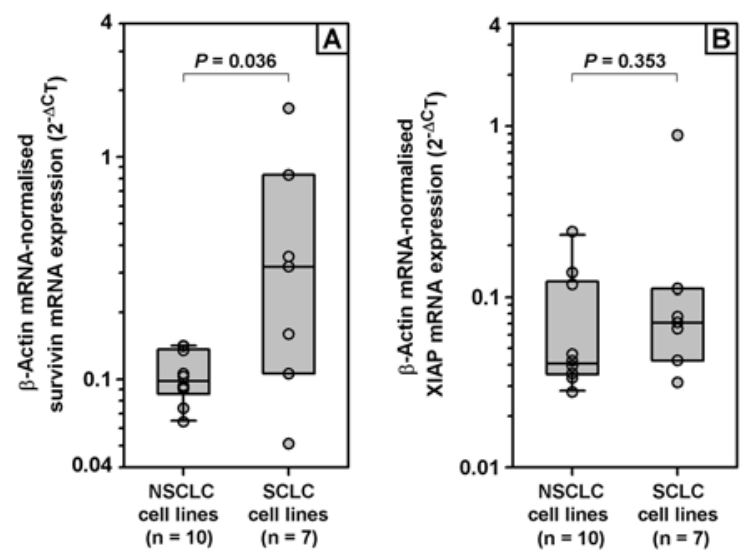

Figure 3. Comparison of survivin mRNA (A) and XIAP mRNA (B) expression, respectively, in non-small cell lung carcinoma (NSCLC) cell lines and small cell lung carcinoma (SCLC) cell lines. In the box plot, the upper and the lower boundary of the box and the line within the box indicate the 75th and 25th percentiles and the median, respectively. The error bars above and below the box indicate the 90th and 10th percentiles. Statistical difference $(\mathrm{P})$ between the transcript expression levels was calculated using the Mann-Whitney test. 
Table II. Real-time RT-PCR analysis of survivin mRNA expression in non-small cell lung carcinomas and lungs.

\begin{tabular}{|c|c|c|c|c|c|c|}
\hline \multirow[b]{2}{*}{ Tumour type } & \multirow[b]{2}{*}{$\mathrm{n}$} & \multicolumn{2}{|c|}{$\begin{array}{c}\text { B-actin mRNA-normalised } \\
\text { expression of survivin mRNA }\left(2^{-\Delta \mathrm{C}_{\mathrm{T}}}\right)^{\mathrm{b}}\end{array}$} & \multirow{2}{*}{$\begin{array}{c}\text { Statistical difference }(\mathrm{P}) \\
\text { of survivin mRNA } \\
\text { expression in } \\
\text { Tu versus } \mathrm{Lu}^{\mathrm{c}}\end{array}$} & \multirow{2}{*}{$\begin{array}{l}\mathrm{Tu} / \mathrm{Lu} \text { ratio of } \\
\text { survivin mRNA } \\
\text { expression }^{\mathrm{b}}\end{array}$} & \multirow{2}{*}{$\begin{array}{c}\text { Number of patients } \\
\text { with Tu/Lu survivin } \\
\text { mRNA expression } \\
\text { ratio } \geq 2 \text { and } \leq 0.5\end{array}$} \\
\hline & & Tumours (Tu) & Lungs (Lu) & & & \\
\hline NSCLC & $150^{\mathrm{a}}$ & $\begin{array}{c}0.01423 \\
(0.00072-0.20590)\end{array}$ & $\begin{array}{c}0.00093 \\
(0.000003-0.01499)\end{array}$ & $2.7 \times 10^{-43}$ & $\begin{array}{c}16.2 \\
(0.7-814.6)\end{array}$ & $142(95 \%)$ and 0 \\
\hline SQCLC & 69 & $\begin{array}{c}0.01663^{\mathrm{d}} \\
(0.00112-0.14865)\end{array}$ & $\begin{array}{c}0.00102 \\
(0.000047-0.00849)\end{array}$ & $1.7 \times 10^{-21}$ & $\begin{array}{c}15.9 \\
(1.1-537.4)\end{array}$ & $66(96 \%)$ and 0 \\
\hline LAC & 56 & $\begin{array}{c}0.00837 \\
(0.00072-0.11344)\end{array}$ & $\begin{array}{c}0.00082 \\
(0.000003-0.00671)\end{array}$ & $1.5 \times 10^{-16}$ & $\begin{array}{c}15.0 \\
(0.7-814.6)\end{array}$ & $52(93 \%)$ and 0 \\
\hline LCLC & 7 & $\begin{array}{c}0.02977^{\mathrm{d}} \\
(0.00286-0.20590)\end{array}$ & $\begin{array}{c}0.00038 \\
(0.000098-0.00613)\end{array}$ & $1.16 \times 10^{-3}$ & $\begin{array}{c}29.0 \\
(3.6-754.8)\end{array}$ & $7(100 \%)$ and 0 \\
\hline SLC & 4 & $\begin{array}{c}0.01838 \\
(0.01296-0.07081)\end{array}$ & $\begin{array}{c}0.00127 \\
(0.000676-0.00709)\end{array}$ & $2.85 \times 10^{-2}$ & $\begin{array}{c}13.0 \\
(2.3-104.7)\end{array}$ & $4(100 \%)$ and 0 \\
\hline UNDIF & 11 & $\begin{array}{c}0.02538^{\mathrm{d}} \\
(0.01024-0.10584)\end{array}$ & $\begin{array}{c}0.00077 \\
(0.000253-0.01499)\end{array}$ & $2.35 \times 10^{-4}$ & $\begin{array}{c}40.5 \\
(0.91-150.1)\end{array}$ & $10(91 \%)$ and 0 \\
\hline
\end{tabular}

${ }^{\mathrm{a}} \mathrm{A}$ total of 150 NSCLC patients was studied including 69 patients with squamous cell lung carcinoma (SQCLC), 56 patients with lung adenocarcinoma (LAC), 3 patients with SQCLC+LAC mixed-type tumours, 7 patients with large-cell lung carcinoma (LCLC), 4 patients with sarcomatoid lung carcinoma (SLC) and 11 patients with undifferentiated lung carcinoma (UNDIF). ${ }^{b}$ Data are represented as the median with the range in parentheses. ${ }^{c}$ The statistical difference of the $\beta$-actin mRNA-normalised survivin mRNA expression in Tu versus Lu was calculated using the MannWhitney test. ${ }^{\mathrm{d}}$ The B-actin mRNA-normalised survivin mRNA expression in SQCLC, LCLC and UNDIF was significantly higher than in LAC $(\mathrm{P}=0.0029, \mathrm{P}=0.0187$ and $\mathrm{P}=0.0035$, respectively, Mann-Whitney test).

Table III. Immunometric analysis of survivin protein expression in non-small cell lung carcinomas and lungs.

\begin{tabular}{|c|c|c|c|c|c|c|}
\hline \multirow[b]{2}{*}{ Tumour type } & \multirow[b]{2}{*}{$\mathrm{n}$} & \multicolumn{2}{|c|}{$\begin{array}{l}\text { Survivin protein expression } \\
(\mathrm{ng} / \mathrm{mg} \text { of total protein })^{\mathrm{b}}\end{array}$} & \multirow{2}{*}{$\begin{array}{c}\text { Statistical difference }(\mathrm{P}) \\
\text { of survivin protein } \\
\text { expression in } \\
\text { Tu versus } \mathrm{Lu}^{\mathrm{c}}\end{array}$} & \multirow{2}{*}{$\begin{array}{l}\mathrm{Tu} / \mathrm{Lu} \text { ratio of } \\
\text { survivin protein } \\
\text { expression }^{\mathrm{b}}\end{array}$} & \multirow{2}{*}{$\begin{array}{c}\text { Number of patients } \\
\text { with } \mathrm{Tu} / \mathrm{Lu} \text { survivin } \\
\text { protein expression } \\
\text { ratio } \geq 2 \text { and } \leq 0.5\end{array}$} \\
\hline & & Tumours (Tu) & Lungs (Lu) & & & \\
\hline NSCLC & $88^{\mathrm{a}}$ & $\begin{array}{c}2.383 \\
(0.107-15.901)\end{array}$ & $\begin{array}{c}0.089 \\
(0.010-0.501)\end{array}$ & $4.7 \times 10^{-29}$ & $\begin{array}{c}23.5 \\
(1.1-720)\end{array}$ & $85(97 \%)$ and 0 \\
\hline SQCLC & 39 & $\begin{array}{c}2.148 \\
(0.107-15.901)\end{array}$ & $\begin{array}{c}0.083 \\
(0.015-0.325)\end{array}$ & $3.2 \times 10^{-13}$ & $\begin{array}{c}27.2 \\
(1.1-166.2)\end{array}$ & $37(95 \%)$ and 0 \\
\hline LAC & 38 & $\begin{array}{c}2.189 \\
(0.224-11.365)\end{array}$ & $\begin{array}{c}0.079 \\
(0.014-0.469)\end{array}$ & $7.8 \times 10^{-14}$ & $\begin{array}{c}24.0 \\
(1.7-142.7)\end{array}$ & $37(97 \%)$ and 0 \\
\hline
\end{tabular}

aA total of 88 NSCLC patients was studied including 39 patients with SQCLC, 38 patients with LAC, 3 patients with SQCLC+LAC mixed-type tumours, 2 patients with LCLC, 3 patients with SLC, and 3 patients with UNDIF. ${ }^{b}$ Data are represented as the median with the range in parentheses. cStatistical difference of survivin protein expression in Tu versus Lu was calculated using the Mann-Whitney test.

of smoking and non-smoking LAC patients ( $\mathrm{P}>0.07$; MannWhitney test).

The expression of HBXIP mRNA, whose protein product functions as a co-factor for survivin in one of its apoptosis suppression mechanisms (3) in the studied NSCLC cell lines

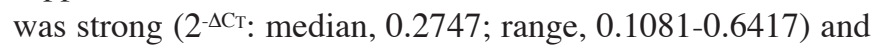
significantly higher as compared to NSCLC tissues and lungs (Table V; $\mathrm{P}=2.2 \times 10^{-4}$ and $\mathrm{P}=6.8 \times 10^{-5}$, respectively; Mann-
Whitney test). The expression of HBXIP mRNA in NSCLC tissues, except SLC, and matched lungs was not significantly different, and NSCLC tumours of different histopathological types expressed comparable levels of HBXIP mRNA (Table V). The number of patients with a tumour/lung HBXIP mRNA expression ratio $>2$ was relatively low in the group of all examined NSCLC patients (Table V), and there was no statistically significant impact of patient gender and smoking 

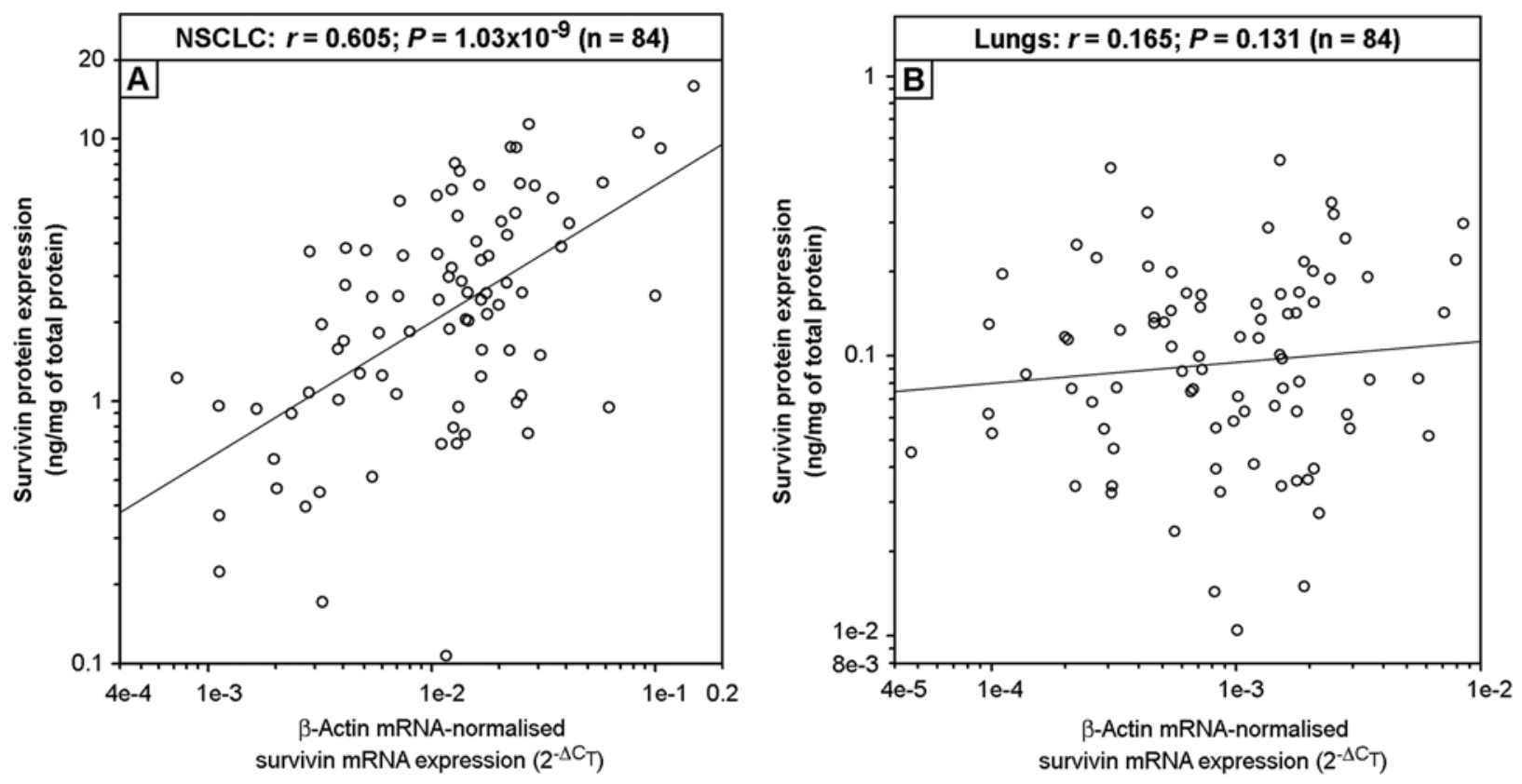

Figure 4. Correlation analysis of survivin mRNA and protein expression in non-small cell lung carcinoma (NSCLC) tissues (A) and lungs (B). Pearson linear correlation coefficients $\mathrm{r}$ and their P-value are indicated.
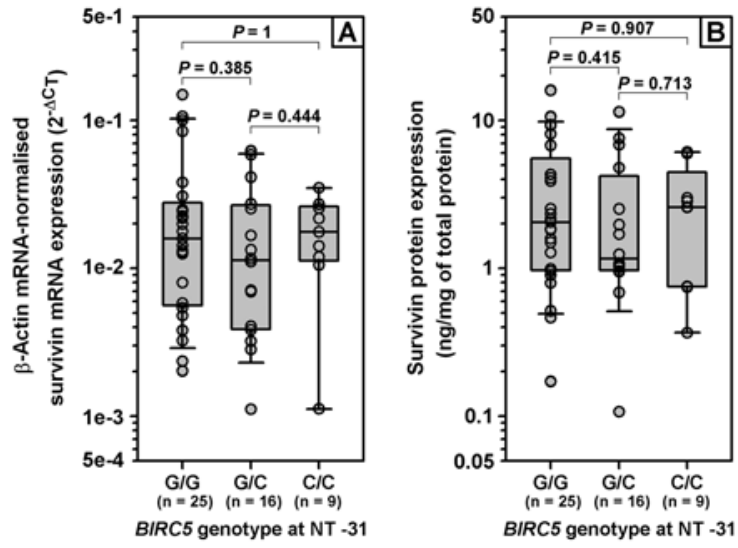

Figure 5. BIRC5 promoter polymorphism at nucleotide -31 and the level of survivin mRNA (A) and survivin protein (B) expression in non-small cell lung carcinoma tissues. In the box plot, the upper and the lower boundary of the box and the line within the box indicate the 75th and 25th percentiles and the median, respectively. The error bars above and below the box indicate the 90th and 10th percentiles. Statistical difference $(\mathrm{P})$ between the indicated genotype categories was calculated using the Mann-Whitney test.

habit, tumour grade and tumour stage on the expression of HBXIP mRNA in NSCLC tissues ( $>>0.11$, Mann-Whitney test, data not shown).

The expression of XIAP mRNA in NSCLC tissues and matched lungs was not significantly different, and NSCLC tumours of different histopathological types showed comparable levels of XIAP mRNA (Table VI). In contrast, the expression of XIAP protein in NSCLC tissues, particularly in LACs, was significantly higher as compared to matched lungs (Table VII). Nevertheless, the number of patients with a tumour/lung XIAP mRNA and XIAP protein expression ratio $>2$ was relatively low in the groups of all examined
NSCLC patients (Tables VI and VII). There was no correlation between XIAP mRNA and protein expression in the tumours and the lungs (Fig. 6). The expression of both XIAP mRNA and protein in the studied NSCLC tissues and NSCLC cell lines was not significantly different $(\mathrm{P}>0.78$; Mann-Whitney test). Patient gender, tumour grade and tumour stage did not have any significant impact on the expression of XIAP mRNA and protein in NSCLC tissues. The tumours of smokers showed a significantly lower expression of XIAP protein, but not of mRNA, as compared to the tumours of non-smokers (Table VIII). However, when LACs were considered separately, the expression of XIAP protein in the tumours of smoking and non-smoking LAC patients was not statistically significant ( $P>0.12$; MannWhitney test).

Although the molar levels of survivin and XIAP proteins were not significantly different in NSCLC cell lines (median/ range, 538.5/214.5-942.0 and 682.9/202.6-1583.5 fmol/mg of total protein, respectively; $\mathrm{P}=0.34$, Mann-Whitney test, $\mathrm{n}=10$ ) the molar level of survivin protein was significantly lower than that of XIAP protein in NSCLC tissues (median/range, 145.4/6.5-970.1 and 599.8/4.3-1987.4 fmol/mg, respectively; $\mathrm{P}=7.4 \times 10^{-18}$, Mann-Whitney test, $\mathrm{n}=88$ ). There was no correlation between the expression of survivin and XIAP proteins in NSCLC cell lines and NSCLC tissues or lungs.

\section{Discussion}

The results of the present study provide evidence that both survivin mRNA and protein are overexpressed in NSCLC cell lines and NSCLC tumours of different histopathological subtypes. Considering the major histopathological types of NSCLC and the degree of their differentiation, the expression of survivin mRNA was significantly higher in SQCLCs as compared to LACs, and significantly higher in the less- 
Table IV. Impact of gender, smoking, tumour grade, and tumour stage on survivin mRNA and survivin protein expression in non-small cell lung carcinoma.

\begin{tabular}{|c|c|c|c|c|c|c|}
\hline Category & $\mathrm{n}^{\mathrm{a}}$ & $\begin{array}{c}\text { } \text {-actin mRNA-normalised } \\
\text { expression of survivin mRNA }\left(2^{-\Delta \mathrm{CT}}\right)^{\mathrm{b}}\end{array}$ & $\begin{array}{c}\text { Statistical } \\
\text { difference }(\mathrm{P})^{\mathrm{c}}\end{array}$ & $\mathrm{n}^{\mathrm{a}}$ & $\begin{array}{l}\text { Survivin protein expression } \\
\text { (ng/mg of total protein })^{\mathrm{b}}\end{array}$ & $\begin{array}{c}\text { Statistical } \\
\text { difference }(\mathrm{P})^{\mathrm{c}}\end{array}$ \\
\hline \multicolumn{7}{|l|}{ Gender } \\
\hline Men & 110 & $0.01618(0.00129-0.20590)$ & 0.001 & 58 & $2.549(0.107-15.901)$ & 0.529 \\
\hline Women & 40 & $0.00647(0.00072-0.11344)$ & & 30 & $1.638(0.224-11.365)$ & \\
\hline \multicolumn{7}{|l|}{ Smoking } \\
\hline Non-smokers & 20 & $0.00625(0.00072-0.05831)$ & 0.011 & 13 & $1.276(0.224-11.365)$ & 0.371 \\
\hline Smokers & 130 & $0.01595(0.00111-0.62417)$ & & 75 & $2.465(0.107-15.901)$ & \\
\hline \multicolumn{7}{|l|}{ Tumour grade } \\
\hline Grade $1+2$ & 69 & $0.01060(0.00072-0.11344)$ & 0.007 & 33 & $2.333(0.172-10.555)$ & 0.298 \\
\hline Grade 3 & 54 & $0.01722(0.00112-0.07081)$ & & 42 & $2.701(0.107-15.901)$ & \\
\hline \multicolumn{7}{|l|}{ Tumour stage } \\
\hline Stage IA & 21 & $0.00744(0.00112-0.05872)$ & & 13 & $1.011(0.172-5.944)$ & \\
\hline Stage IB & 62 & $0.01505(0.00111-0.20590)$ & 0.054 & 32 & $2.474(0.107-11.365)$ & 0.049 \\
\hline Stage II+III & 63 & $0.01584(0.00072-0.14865)$ & 0.122 & 40 & $2.099(0.197-15.901)$ & 0.044 \\
\hline
\end{tabular}

aThe number, $\mathrm{n}$, of examined NSCLC tissues belonging to the particular category is indicated. ${ }^{\mathrm{b}}$ Data are represented as the median with the range in parentheses. 'Statistical difference between NSCLC tissues belonging to the particular category was calculated using the Mann-Whitney test. The levels of survivin mRNA and protein expression in stage IB tumours and stage II+III tumours were compared, respectively, with those in stage IA tumours.

Table V. Real-time RT-PCR analysis of HBXIP mRNA expression in non-small cell lung carcinomas and lungs.

\begin{tabular}{|c|c|c|c|c|c|c|}
\hline \multirow[b]{2}{*}{ Tumour type } & \multirow[b]{2}{*}{$\mathrm{n}$} & \multicolumn{2}{|c|}{$\begin{array}{c}\text { ß-actin mRNA-normalised } \\
\text { expression of HBXIP mRNA }\left(2^{-\Delta C_{T}}\right)^{b}\end{array}$} & \multirow{2}{*}{$\begin{array}{c}\text { Statistical difference }(\mathrm{P}) \\
\text { of HBXIP mRNA } \\
\text { expression in } \\
\text { Tu versus } \mathrm{Lu}^{\mathrm{c}}\end{array}$} & \multirow{2}{*}{$\begin{array}{c}\mathrm{Tu} / \mathrm{Lu} \text { ratio of } \\
\text { HBXIP mRNA } \\
\text { expression }^{\mathrm{b}}\end{array}$} & \multirow{2}{*}{$\begin{array}{l}\text { Number of patients } \\
\text { with Tu/Lu HBXIP } \\
\text { mRNA expression } \\
\text { ratio } \geq 2 \text { and } \leq 0.5\end{array}$} \\
\hline & & Tumours (Tu) & Lungs $(\mathrm{Lu})$ & & & \\
\hline NSCLC & $68^{\mathrm{a}}$ & $\begin{array}{c}0.1001 \\
(0.0018-2.0994)\end{array}$ & $\begin{array}{c}0.1088 \\
(0.0118-0.5743)\end{array}$ & 0.752 & $\begin{array}{c}0.99 \\
(0.01-5.35)\end{array}$ & $17(26 \%)$ and $12(19 \%)$ \\
\hline SQCLC & 30 & $\begin{array}{c}0.0932 \\
(0.0143-0.3737)\end{array}$ & $\begin{array}{c}0.1304 \\
(0.0198-0.3299)\end{array}$ & 0.307 & $\begin{array}{c}0.97 \\
(0.08-3.05)\end{array}$ & $5(17 \%)$ and $8(27 \%)$ \\
\hline LAC & 22 & $\begin{array}{c}0.1189 \\
(0.0018-0.6736)\end{array}$ & $\begin{array}{c}0.1077 \\
(0.0118-0.3392)\end{array}$ & 0.589 & $\begin{array}{c}1.18 \\
(0.01-5.35)\end{array}$ & $7(32 \%)$ and $3(14 \%)$ \\
\hline LCLC & 5 & $\begin{array}{c}0.1476 \\
(0.0638-2.0994)\end{array}$ & $\begin{array}{c}0.1134 \\
(0.0364-0.5743)\end{array}$ & 0.547 & $\begin{array}{c}2.71 \\
(0.73-3.65)\end{array}$ & $3(60 \%)$ and 0 \\
\hline SLC & 4 & $\begin{array}{c}0.0417 \\
(0.0326-0.0487)\end{array}$ & $\begin{array}{c}0.0706 \\
(0.0612-0.1134)\end{array}$ & 0.028 & $\begin{array}{c}0.50 \\
(0.40-0.79)\end{array}$ & 0 and $2(50 \%)$ \\
\hline UNDIF & 7 & $\begin{array}{c}0.1330 \\
(0.0470-0.1550)\end{array}$ & $\begin{array}{c}0.1096 \\
(0.0369-0.2176)\end{array}$ & 1 & $\begin{array}{c}1.27 \\
(0.31-2.34)\end{array}$ & $2(28 \%)$ and $1(14 \%)$ \\
\hline
\end{tabular}

aA total of 68 NSCLC patients was studied including 30 patients with SQCLC, 22 patients with LAC, 5 patients with LCLC, 4 patients with SLC and 7 patients with UNDIF. ${ }^{b}$ Data are represented as the median with the range in parentheses. ${ }^{c}$ Statistical difference of the $B$-actin mRNA-normalised expression of HBXIP mRNA in Tu versus Lu was calculated using the Mann-Whitney test.

differentiated than in the well-differentiated SQCLCs and LACs, respectively. These findings confirm previously reported results $(56,57)$. Although the expression of survivin mRNA in stage IB and stage II+III tumours was higher than in stage IA tumours, this difference did not reach statistical significance. Nevertheless, we found that the expression of survivin protein was significantly upregulated in stage IB tumours and stage II+III tumours as compared to stage IA tumours. These immunometric data are consistent with previously reported immunohistochemical findings (56) and 
Table VI. Real-time RT-PCR analysis of XIAP mRNA expression in non-small cell lung carcinomas and lungs.

\begin{tabular}{|c|c|c|c|c|c|c|}
\hline \multirow[b]{2}{*}{ Tumour type } & \multirow[b]{2}{*}{$\mathrm{n}$} & \multicolumn{2}{|c|}{$\begin{array}{c}\text { ß-actin mRNA-normalised } \\
\text { expression of XIAP mRNA }\left(2^{-\Delta C_{T}}\right)^{b}\end{array}$} & \multirow{2}{*}{$\begin{array}{c}\text { Statistical difference }(\mathrm{P}) \\
\text { of XIAP mRNA } \\
\text { expression in } \\
\text { Tu versus } \mathrm{Lu}^{\mathrm{c}}\end{array}$} & \multirow{2}{*}{$\begin{array}{c}\text { Tu/Lu ratio of } \\
\text { XIAP mRNA } \\
\text { expression }^{\text {b }}\end{array}$} & \multirow{2}{*}{$\begin{array}{l}\text { Number of patients } \\
\text { with Tu/Lu XIAP } \\
\text { mRNA expression } \\
\text { ratio } \geq 2 \text { and } \leq 0.5\end{array}$} \\
\hline & & Tumours $(\mathrm{Tu})$ & Lungs (Lu) & & & \\
\hline NSCLC & $150^{\mathrm{a}}$ & $\begin{array}{c}0.06143 \\
(0.00125-0.29321)\end{array}$ & $\begin{array}{c}0.05892 \\
(0.01017-0.30355)\end{array}$ & 0.659 & $\begin{array}{c}0.90 \\
(0.03-8.28)\end{array}$ & $12(8 \%)$ and $21(14 \%)$ \\
\hline SQCLC & 69 & $\begin{array}{c}0.05954 \\
(0.01075-0.16724)\end{array}$ & $\begin{array}{c}0.05913 \\
(0.01017-0.28127)\end{array}$ & 0.726 & $\begin{array}{c}0.87 \\
(0.32-8.28)\end{array}$ & $3(4 \%)$ and $6(9 \%)$ \\
\hline LAC & 56 & $\begin{array}{c}0.06359 \\
(0.00617-0.29321)\end{array}$ & $\begin{array}{c}0.05852 \\
(0.01332-0.30355)\end{array}$ & 0.960 & $\begin{array}{c}0.94 \\
(0.22-3.84)\end{array}$ & $8(14 \%)$ and $10(18 \%)$ \\
\hline LCLC & 7 & $\begin{array}{c}0.06745 \\
(0.03691-0.12763)\end{array}$ & $\begin{array}{c}0.06381 \\
(0.04419-0.10153)\end{array}$ & 0.898 & $\begin{array}{c}1.10 \\
(0.42-2.00)\end{array}$ & $1(14 \%)$ and $1(14 \%)$ \\
\hline SLC & 4 & $\begin{array}{c}0.03470 \\
(0.00982-0.05441)\end{array}$ & $\begin{array}{c}0.06460 \\
(0.02435-0.09408)\end{array}$ & 0.200 & $\begin{array}{c}0.49 \\
(0.38-0.76)\end{array}$ & 0 and $2(50 \%)$ \\
\hline UNDIF & 11 & $\begin{array}{c}0.05441 \\
(0.02836-0.13870)\end{array}$ & $\begin{array}{c}0.05913 \\
(0.02521-0.20166)\end{array}$ & 0.947 & $\begin{array}{c}0.98 \\
(0.43-1.51)\end{array}$ & 0 and $1(9 \%)$ \\
\hline
\end{tabular}

${ }^{a} \mathrm{~A}$ total of 150 NSCLC patients was studied including 69 patients with SQCLC, 56 patients with LAC, 3 patients with SQCLC+LAC mixed-type tumours, 7 patients with LCLC, 4 patients with SLC, and 11 patients with UNDIF. b Data are represented as the median with the range in parentheses. ${ }^{c}$ Statistical difference of the B-actin mRNA-normalised XIAP mRNA expression in Tu versus Lu was calculated using the MannWhitney test.

Table VII. Immunometric analysis of XIAP protein expression in non-small cell lung carcinomas and lungs.

\begin{tabular}{|c|c|c|c|c|c|c|}
\hline \multirow[b]{2}{*}{ Tumour type } & \multirow[b]{2}{*}{$\mathrm{n}$} & \multicolumn{2}{|c|}{ 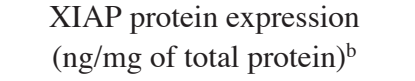 } & \multirow{2}{*}{$\begin{array}{l}\text { Statistical difference }(\mathrm{P}) \\
\text { of XIAP protein } \\
\text { expression in } \\
\text { Tu versus } \mathrm{Lu}^{\mathrm{c}}\end{array}$} & \multirow{2}{*}{$\begin{array}{l}\mathrm{Tu} / \mathrm{Lu} \text { ratio of } \\
\text { XIAP protein } \\
\text { expression }^{\mathrm{b}}\end{array}$} & \multirow{2}{*}{$\begin{array}{l}\text { Number of patients } \\
\text { with } \mathrm{Tu} / \mathrm{Lu} \text { XIAP } \\
\text { protein expression } \\
\text { ratio } \geq 2 \text { and } \leq 0.5\end{array}$} \\
\hline & & Tumours $(\mathrm{Tu})$ & Lungs (Lu) & & & \\
\hline NSCLC & $88^{\mathrm{a}}$ & $\begin{array}{c}34.01 \\
(0.24-112.70)\end{array}$ & $\begin{array}{c}29.93 \\
(3.40-76.40)\end{array}$ & 0.017 & $\begin{array}{c}1.3 \\
(0.01-8.3)\end{array}$ & $14(16 \%)$ and $12(14 \%)$ \\
\hline SQCLC & 39 & $\begin{array}{c}32.86 \\
(0.24-86.27)\end{array}$ & $\begin{array}{c}30.07 \\
(3.40-69.46)\end{array}$ & 0.280 & $\begin{array}{c}1.1 \\
(0.01-8.1)\end{array}$ & $4(10 \%)$ and $5(13 \%)$ \\
\hline LAC & 38 & $\begin{array}{c}41.47 \\
(0.73-112.70)\end{array}$ & $\begin{array}{c}27.73 \\
(14.05-76.41)\end{array}$ & 0.004 & $\begin{array}{c}1.4 \\
(0.03-5.4)\end{array}$ & $8(21 \%)$ and $4(11 \%)$ \\
\hline
\end{tabular}

${ }^{\mathrm{a}} \mathrm{A}$ total of 88 NSCLC patients was studied including 39 patients with SQCLC, 38 patients with LAC, 3 patients with SQCLC+LAC mixed-type tumours, 2 patients with LCLC, 3 patients with SLC and 3 patients with UNDIF. b'Data are respresented as the median with the range in parentheses. 'Statistical difference of XIAP protein expression in Tu versus Lu was calculated using the Mann-Whitney test.

suggest that survivin may play a role in tumourigenesis and tumour growth of NSCLC. This notion is further substantiated by the immunohistochemical detection of increased survivin protein expression in premalignant stages of lung cancerogenesis including squamous metaplasia, dysplasia and atypical adenomatous hyperplasia (56,58-60).

The expression of survivin mRNA and protein showed a high positive correlation in NSCLC tumours, but there was lack of correlation of their expression in the lungs. The latter result points to the possibility that there may be an accelerated degradation of the weakly expressed survivin protein in normal lung cells, such as bronchial epithelia (59), which can be promoted by the XIAP•XAF1 protein complex (61). This view is supported by ubiquitous expression of XAF1, an antagonist of XIAP anti-caspase activity, in normal cells and tissues including lung (62) as well as by high expression of XIAP in normal cells including bronchial epithelia (63).

Since the occurrence of the C/C genotype at NT -31 in BIRC 5 promoter has been previously correlated with decreased survivin mRNA and protein expression in a variety of cancer cell lines (48), we examined the relationship between the BIRC5 promoter genotype at NT -31 and the 

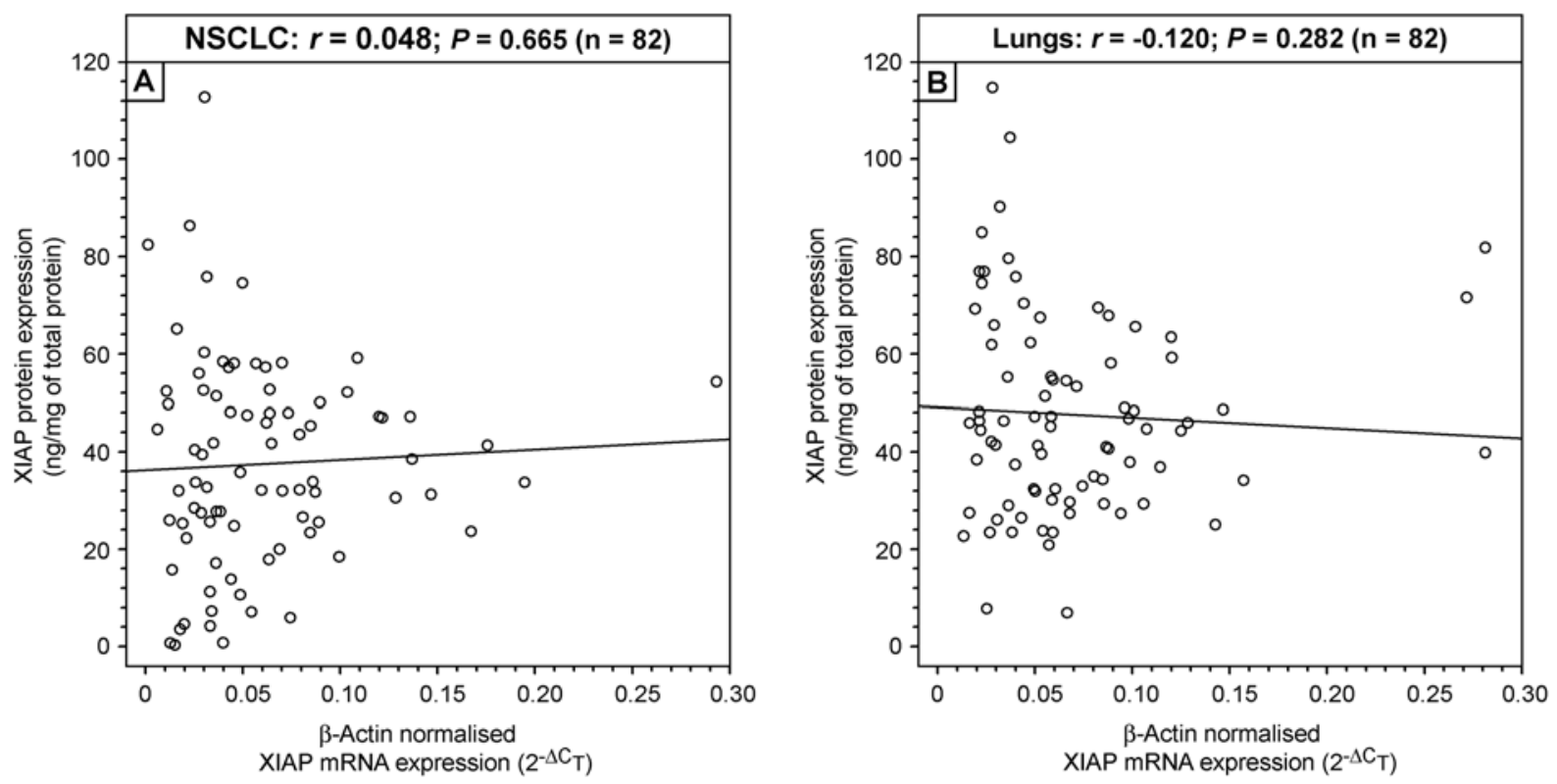

Figure 6. Correlation analysis of XIAP mRNA and protein expression in non-small cell lung carcinoma (NSCLC) tissues (A) and lungs (B). Pearson linear correlation coefficients $r$ and their P-value are indicated.

Table VIII. Impact of gender, smoking, tumour grade, and tumour stage on XIAP mRNA and XIAP protein expression in nonsmall cell lung carcinoma.

\begin{tabular}{|c|c|c|c|c|c|c|}
\hline Category & $\mathrm{n}^{\mathrm{a}}$ & $\begin{array}{c}\text { B-actin mRNA-normalised } \\
\text { expression of XIAP mRNA }\left(2^{-\Delta \mathrm{C} T}\right)^{b}\end{array}$ & $\begin{array}{c}\text { Statistical } \\
\text { difference }(\mathrm{P})^{\mathrm{c}}\end{array}$ & $\mathrm{n}^{\mathrm{a}}$ & 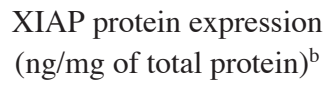 & $\begin{array}{c}\text { Statistical } \\
\text { difference }(\mathrm{P})^{\mathrm{c}}\end{array}$ \\
\hline \multicolumn{7}{|l|}{ Gender } \\
\hline Men & 110 & $0.06315(0.00617-0.28519)$ & 0.553 & 58 & $32.85(0.71-86.27)$ & 0.263 \\
\hline Women & 40 & $0.05241(0.00125-0.29321)$ & & 30 & $40.35(0.24-112.70)$ & \\
\hline \multicolumn{7}{|l|}{ Smoking } \\
\hline Non-smokers & 20 & $0.06381(0.00125-0.28519)$ & 0.746 & 13 & $49.68(5.91-82.39)$ & 0.009 \\
\hline Smokers & 130 & $0.05913(0.00617-0.29321)$ & & 75 & $32.84(0.24-112.70)$ & \\
\hline \multicolumn{7}{|l|}{ Tumour grade } \\
\hline Grade $1+2$ & 67 & $0.05872(0.01075-0.28519)$ & 0.871 & 36 & $32.51(0.71-74.53)$ & 0.205 \\
\hline Grade 3 & 54 & $0.06655(0.00617-0.29321)$ & & 36 & $42.64(0.25-86.27)$ & \\
\hline \multicolumn{7}{|l|}{ Tumour stage } \\
\hline Stage IA & 21 & $0.05441(0.00137-0.12158)$ & & 13 & $45.29(5.91-112.70)$ & \\
\hline Stage IB & 62 & $0.06359(0.00125-0.28519)$ & 0.536 & 32 & $34.01(3.50-86.27)$ & 0.910 \\
\hline Stage II+III & 63 & $0.06293(0.01168-0.29321)$ & 0.260 & 40 & $34.73(0.24-74.53)$ & 0.555 \\
\hline
\end{tabular}

${ }^{a}$ The number, $n$, of examined NSCLC tissues belonging to the particular category is indicated. ${ }^{b}$ Data are represented as the median with the range in parentheses. 'Statistical difference between NSCLC tissues belonging to a particular category was calculated using the Mann-Whitney test. The levels of XIAP mRNA and protein expression in stage IB tumours and stage II+III tumours were compared, respectively, with those in stage IA tumours.

expression of survivin mRNA and protein in NSCLC cell lines and tissues. We found that the expression of both survivin mRNA and protein in the investigated tumour cell lines and tissues was not significantly affected by the BIRC5 promoter genotype at NT -31 . These results are in line with the recently reported immunohistochemical data for the expression of survivin in breast carcinomas (66). The overexpression of both survivin mRNA and protein in NSCLC cells and tissues may be primarily of the transcriptional origin, due to increased co-expression of several BIRC5-targeting transcription factors including E2F-1 (67), Stat3 (68), NF- $\mathrm{B}$ (69), and HIF-1 $\alpha$ (70). Moreover, the proteasomal degradation of survivin protein may be slowed down in NSCLC cells because of survivin ubiquitination inhibition, which can be caused by overexpression of cyclooxygenase-2 $(71,72)$ and/or downregulation of the survivin ubiquitinating XIAP•XAF1 
complex (61) due to low or absent expression of XAF1 in NSCLC cells $(62,64,65)$. The enhanced expression of survivin mRNA in SCLC cell lines as compared to NSCLC cell lines (55, and the present study) suggests that the transcriptional upregulation of BIRC5 gene expression in NSCLC and SCLC cells may be different. Altogether, the high overexpression of the BIRC5 gene in lung tumours offers the rationale for their apoptosis-based therapy that could involve the tumour-specific expression of recombinant DNA constructs consisting of a fusion of the BIRC5 promoter to the coding sequence of an active apoptosis effector such as reverse caspases or granzyme B $(73,74)$.

Survivin can form a protein complex with HBXIP which binds procaspase- 9 and sequesters it from activation in the apoptosome (3). In this study, we found that HBXIP mRNA is abundantly expressed in NSCLC cells and tumours as well as in the lungs. This result together with the differential expression of survivin in lung tumours and lungs indicates that survivin is the limiting factor for the formation of the antiapoptotic survivin•HBXIP complex, which may be preferentially generated in lung tumours to inhibit the apoptosome pathway of apoptosis.

XIAP is the only IAP which directly inhibits the activity of apoptotic caspases including caspase-9, -3 and -7 (9). Contrary to a previous report (75), the present study revealed that the expression of XIAP mRNA in NSCLC cell lines and tissues and lungs was not significantly different. However, we found a significantly increased level of XIAP protein in NSCLC tissues, particularly in LAC tumours, as compared to matched lungs. The latter results and the lack of correlation between the levels of XIAP mRNA and protein in the tumours suggest that the expression of XIAP may be translationally upregulated and/or post-translationally stabilised in tumours. In fact, the translation initiation of XIAP mRNA is internal ribosome entry segment (IRES)-dependent and can be enhanced by several IRES trans-acting factors such as La autoantigen, hnRNP C1/C2 and MDM2 protein (76-78). Furthermore, the level of XIAP in cancer cells can be upregulated through protection against the proteasomal degradation-promoting ubiquitination. Such stabilisation involves phosphorylation of XIAP by the Akt kinase (79) or interaction of XIAP with survivin (8), Notch receptor (80) or p34 $4^{\text {SEI-1 }}$ protein (81). The upregulated expression of XIAP in cancer cells that occurs in response to DNA damage is due to the Che-1 protein- (82) and/or MDM2 protein-mediated (78) activation of XIAP NF-кB-dependent transcription and XIAP IRES-dependent translation, respectively.

Although the molar levels of survivin and XIAP proteins in NSCLC cell lines were not significantly different, the molar level of XIAP protein in NSCLC tumours was significantly higher than that of survivin protein. The latter difference may be due to slower expression of survivin protein rather than by its accelerated degradation since the rates of degradation of survivin and XIAP proteins in cancer cells seem to be similar (83).

The expression of XIAP mRNA and protein in NSCLC tumours did not show any significant relationship to clinicopathological factors such as gender, tumour histology, differentiation and stage. These results are in line with previously reported data on XIAP expression in NSCLC tumours
$(75,84,85)$. Although the expression of XIAP and cIAPs in NSCLC tumours did not predict the response to classic chemotherapy in patients with advanced NSCLC (84), treatment of NSCLC cells as well as other cancer cells with novel synthetic Smac-mimetic antagonists of XIAP and cIAPs induces apoptosis in these cells $(35,36,86,87)$ or sensitises them against apoptosis inducers such as nonsteroidal anti-inflammatory drugs and TRAIL $(88,89)$.

\section{Acknowledgements}

This work was supported by a grant (no. NR/7860-5) and an institutional research project (no. MZO 00064211) from the Ministry of Health, Czech Republic.

\section{References}

1. Srinivasula SM and Ashwell JD: IAPs: what's in a name? Mol Cell 30: 123-135, 2008.

2. LaCasse EC, Mahoney DJ, Cheung HH, Plenchette S, Baird S and Korneluk RG: IAP-targeted therapies for cancer. Oncogene 27: 6252-6275, 2008

3. Marusawa H, Matsuzawa S, Welsh K, Zou H, Armstrong R, Tamm I and Reed JC: HBXIP functions as a cofactor of survivin in apoptosis suppression. EMBO J 22: 2729-2740, 2003.

4. Broemer $\mathrm{M}$ and Meier P: Ubiquitin-mediated regulation of apoptosis. Trends Cell Biol 19: 130-140, 2009.

5. Srinivasula SM, Hegde R, Saleh A, et al: A conserved XIAPinteraction motif in caspase- 9 and Smac/DIABLO regulates caspase activity and apoptosis. Nature 410: 112-116, 2001.

6. Shiozaki EN, Chai J, Rigotti DJ, et al: Mechanism of XIAPmediated inhibition of caspase-9. Mol Cell 11: 519-527, 2003.

7. Scott FL, Denault JB, Riedl SJ, Shin H, Renatus $M$ and Salvesen GS: XIAP inhibits caspase-3 and -7 using two binding sites: evolutionarily conserved mechanism of IAPs. EMBO J 24: 645-655, 2005.

8. Dohi T, Okada K, Xia F, et al: An IAP-IAP complex inhibits apoptosis. J Biol Chem 279: 34087-34090, 2004.

9. Eckelman BP, Salvesen GS and Scott FL: Human inhibitor of apoptosis proteins: why XIAP is the black sheep of the family. EMBO Rep 7: 988-994, 2006.

10. Morizane Y, Honda R, Fukami K and Yasuda H: X-linked inhibitor of apoptosis functions as ubiquitin ligase toward mature caspase-9 and cytosolic Smac/DIABLO. J Biochem 137: 125-132, 2005.

11. Suzuki Y, Nakabayashi Y and Takahashi R: Ubiquitin-protein ligase activity of $\mathrm{X}$-linked inhibitor of apoptosis protein promotes proteasomal degradation of caspase- 3 and enhances its anti-apoptotic effect in Fas-induced cell death. Proc Natl Acad Sci USA 98: 8662-8667, 2001.

12. Astier AL, Svoboda M, Hinds E, De Beaumont R, Munoz O and Freedman AS: Integrins regulate survival of pre-B-ALL cells through differential IAP and caspase-7 ubiquitination and degradation. Leukemia 18: 873-875, 2004.

13. Choi YE, Butterworth M, Malladi S, Duckett CS, Cohen GM and Bratton SB: The E3 ubiquitin ligase cIAP1 binds and ubiquitinates caspases-3 and -7 via unique mechanisms at distinct steps in their processing. J Biol Chem 284: 12772-12782, 2009.

14. Hao Y, Sekine K, Kawabata A, et al: Apollon ubiquitinates Smac and caspase-9, and has an essential cytoprotection function. Nat Cell Biol 6: 849-860, 2004.

15. Martinez-Ruiz G, Maldonado V, Ceballos-Cancino G, ReyesGrajeda JP and Melendez-Zajgla J: Role of Smac/DIABLO in cancer progression. J Exp Clin Cancer Res 27: 48, 2008.

16. Vande Walle L, Lamkanfi M and Vandenabeele P: The mitochondrial serine protease HtrA2/Omi: an overview. Cell Death Differ 15: 453-460, 2008.

17. $\mathrm{Hu} \mathrm{S}$ and Yang X: Cellular inhibitor of apoptosis 1 and 2 are ubiquitin ligases for the apoptosis inducer Smac/DIABLO. J Biol Chem 278: 10055-10060, 2003.

18. Vucic D, Franklin MC, Wallweber HJ, et al: Engineering ML-IAP to produce an extraordinarily potent caspase 9 inhibitor: implications for Smac-dependent anti-apoptotic activity of ML-IAP. Biochem J 385: 11-20, 2005. 
19. Ma L, Huang Y, Song Z, et al: Livin promotes Smac/DIABLO degradation by ubiquitin-proteasome pathway. Cell Death Differ 13: 2079-2088, 2006.

20. Sekine K, Hao Y, Suzuki Y, Takahashi R, Tsuruo T and Naito M: HtrA2 cleaves apollon and induces cell death by IAP-binding motif in apollon-deficient cells. Biochem Biophys Res Commun 330: 279-285, 2005

21. Lee CH, Jeon YT, Kim SH and Song YS: NF-kappaB as a potential molecular target for cancer therapy. Biofactors 29: 19-35, 2007.

22. Lu M, Lin SC, Huang Y, et al: XIAP induces NF-kappaB activation via the BIR1/TAB1 interaction and BIR1 dimerization. Mol Cell 26: 689-702, 2007

23. Hofer-Warbinek R, Schmid JA, Stehlik C, Binder BR, Lipp J and de Martin R: Activation of NF-kappa B by XIAP, the X chromosome-linked inhibitor of apoptosis, in endothelial cells involves TAK1. J Biol Chem 275: 22064-22068, 2000.

24. Hanahan D and Weinberg RA: The hallmarks of cancer. Cell 100: 57-70, 2000.

25. Brown JM and Attardi LD: The role of apoptosis in cancer development and treatment response. Nat Rev Cancer 5: 231-237, 2005.

26. Fulda S: Tumor resistance to apoptosis. Int J Cancer 124: 511-515, 2009.

27. Krajewska M, Krajewski S, Banares S, et al: Elevated expression of inhibitor of apoptosis proteins in prostate cancer. Clin Cancer Res 9: 4914-4925, 2003.

28. Nemoto T, Kitagawa M, Hasegawa M, et al: Expression of IAP family proteins in esophageal cancer. Exp Mol Pathol 76: 253-259, 2004.

29. Lopes RB, Gangeswaran R, McNeish IA, Wang Y and Lemoine NR: Expression of the IAP protein family is dysregulated in pancreatic cancer cells and is important for resistance to chemotherapy. Int J Cancer 120: 2344-2352, 2007.

30. Gordon G, Mani M, Mukhopadhyay L, et al: Expression patterns of inhibitor of apoptosis proteins in malignant pleural mesothelioma. J Pathol 211: 447-454, 2007.

31. Yang L, Cao Z, Yan H and Wood WC: Coexistence of high levels of apoptotic signaling and inhibitor of apoptosis proteins in human tumor cells: implication for cancer specific therapy. Cancer Res 63: 6815-6824, 2003

32. Cummins JM, Kohli M, Rago C, Kinzler KW, Vogelstein B and Bunz F: X-linked inhibitor of apoptosis protein (XIAP) is a nonredundant modulator of tumor necrosis factor-related apoptosis-inducing ligand (TRAIL)-mediated apoptosis in human cancer cells. Cancer Res 64: 3006-3008, 2004

33. Dohi T, Beltrami E, Wall NR, Plescia J and Altieri DC: Mitochondrial survivin inhibits apoptosis and promotes tumorigenesis. J Clin Invest 114: 1117-1127, 2004.

34. Ravi R, Fuchs EJ, Jain A, et al: Resistance of cancers to immunologic cytotoxicity and adoptive immunotherapy via $\mathrm{X}$ linked inhibitor of apoptosis protein expression and coexisting defects in mitochondrial death signaling. Cancer Res 66: 1730-1739, 2006.

35. Lu J, Bai L, Sun H, et al: SM-164: a novel, bivalent Smac mimetic that induces apoptosis and tumor regression by concurrent removal of the blockade of cIAP-1/2 and XIAP. Cancer Res 68 : 9384-9393, 2008

36. Galban S, Hwang C, Rumble JM, et al: Cytoprotective effects of IAPs revealed by a small molecule antagonist. Biochem J 417: 765-771, 2009

37. Ueda Y, Nakagawa T, Kubota T, Ido K and Sato K: Glioma cells under hypoxic conditions block the brain microvascular endothelial cell death induced by serum starvation. J Neurochem 95: 99-110, 2005

38. Virrey JJ, Guan S, Li W, Schonthal AH, Chen TC and Hofman FM Increased survivin expression confers chemoresistance to tumor-associated endothelial cells. Am J Pathol 173: 575-585, 2008

39. Byun SS, Yeo WG, Lee SE and Lee E: Expression of survivin in renal cell carcinomas: association with pathologic features and clinical outcome. Urology 69: 34-37, 2007.

40. Prager GW, Mihaly J, Brunner PM, Koshelnick Y, HoyerHansen G and Binder BR: Urokinase mediates endothelial cel survival via induction of the X-linked inhibitor of apoptosis protein. Blood 113: 1383-1390, 2009.

41. Hu Y, Cherton-Horvat G, Dragowska V, et al: Antisense oligonucleotides targeting XIAP induce apoptosis and enhance chemotherapeutic activity against human lung cancer cells in vitro and in vivo. Clin Cancer Res 9: 2826-2836, 2003.
42. Cao C, Mu Y, Hallahan DE and Lu B: XIAP and survivin as therapeutic targets for radiation sensitization in preclinical models of lung cancer. Oncogene 23: 7047-7052, 2004.

43. Lu B, Mu Y, Cao C, et al: Survivin as a therapeutic target for radiation sensitization in lung cancer. Cancer Res 64: 2840-2845, 2004.

44. Dong F, Guo W, Zhang L, Wu S, Teraishi F, Davis JJ and Fang B: Downregulation of XIAP and induction of apoptosis by the synthetic cyclin-dependent kinase inhibitor GW8510 in nonsmall cell lung cancer cells. Cancer Biol Ther 5: 165-170, 2006.

45. Iwasa T, Okamoto I, Suzuki M, et al: Radiosensitizing effect of YM155, a novel small-molecule survivin suppressant, in nonsmall cell lung cancer cell lines. Clin Cancer Res 14: 6496-6504, 2008.

46. Travis WD, Brambilla E, Müller-Hermelink HK and Harris CC (eds): Pathology and Genetics of Tumours of the Lung, Pleura, Thymus and Heart. IARC Press, Lyon, 2004.

47. Mountain CF: Revisions in the International System for Staging Lung Cancer. Chest 11: 1710-1717, 1997.

48. Xu Y, Fang F, Ludewig G, Jones G and Jones D: A mutation found in the promoter region of the human survivin gene is correlated to overexpression of survivin in cancer cells. DNA Cell Biol 23: 419-429, 2004

49. Livak KJ and Schmittgen TD: Analysis of relative gene expression data using real-time quantitative PCR and the $2^{-\Delta \Delta C_{7}}$ method. Methods 25: 402-408, 2001.

50. Krepela E, Prochazka J, Fiala P, Zatloukal P and Selinger P: Expression of apoptosome pathway-related transcripts in nonsmall cell lung cancer. J Cancer Res Clin Oncol 132: 57-68, 2006.

51. Smith PK, Krohn RI, Hermanson GT, et al: Measurement of protein using bicinchoninic acid. Anal Biochem 150: 76-85, 1985.

52. Schägger H and von Jagow G: Tricine-sodium dodecylsulfatepolyacrylamide gel electrophoresis for the separation of proteins in the range from 1 to $100 \mathrm{kDa}$. Anal Biochem 166: 368-379, 1987.

53. Krepela E, Prochazka J, Liu X, Fiala P and Kinkor Z: Increased expression of Apaf- 1 and procaspase- 3 and the functionality of intrinsic apoptosis apparatus in non-small cell lung carcinoma. Biol Chem 385: 153-168, 2004

54. Ekedahl J, Joseph B, Grigoriev M, Muller M, Magnusson C, Lewensohn R and Zhivotovsky B: Expression of inhibitor of apoptosis proteins in small- and non-small-cell lung carcinoma cells. Exp Cell Res 279: 277-290, 2002.

55. Belyanskaya LL, Hopkins-Donaldson S, Kurtz S, et al: Cisplatin activates Akt in small cell lung cancer cells and attenuates apoptosis by survivin upregulation. Int J Cancer 117: 755-763, 2005

56. Falleni M, Pellegrini C, Marchetti A, et al: Survivin gene expression in early-stage non-small cell lung cancer. J Pathol 200: 620-626, 2003.

57. Nakano J, Huang CL, Liu D, Ueno M, Sumitomo S and Yokomise H: Survivin gene expression is negatively regulated by the p53 tumor suppressor gene in non-small cell lung cancer. Int J Oncol 27: 1215-1221, 2005.

58. Akyurek N, Memis L, Ekinci O, Kokturk N and Ozturk C: Survivin expression in pre-invasive lesions and non-small cell lung carcinoma. Virchows Arch 449: 164-170, 2006.

59. Jin Q, Feng L, Behrens C, Bekele BN, Wistuba II, Hong WK and Lee HY: Implication of AMP-activated protein kinase and Akt-regulated survivin in lung cancer chemopreventive activities of deguelin. Cancer Res 67: 11630-11639, 2007.

60. Nakanishi K, Kawai T, Kumaki F, Hiroi S, Mukai M and Ikeda E: Survivin expression in atypical adenomatous hyperplasia of the lung. Am J Clin Pathol 120: 712-719, 2003.

61. Arora V, Cheung HH, Plenchette S, Micali OC, Liston P and Korneluk RG: Degradation of survivin by the X-linked inhibitor of apoptosis (XIAP)-XAF1 complex. J Biol Chem 282: 26202-26209, 2007.

62. Liston P, Fong WG, Kelly NL, et al: Identification of XAF1 as an antagonist of XIAP anti-caspase activity. Nat Cell Biol 3: 128-133, 2001.

63. Vischioni B, van der Valk P, Span SW, Kruyt FA, Rodriguez JA and Giaccone G: Expression and localization of inhibitor of apoptosis proteins in normal human tissues. Hum Pathol 37: 78-86, 2006.

64. Fong WG, Liston P, Rajcan-Separovic E, St Jean M, Craig C and Korneluk RG: Expression and genetic analysis of XIAPassociated factor 1 (XAF1) in cancer cell lines. Genomics 70 : $113-122,2000$. 
65. Plenchette S, Cheung HH, Fong WG, LaCasse EC and Korneluk RG: The role of XAF1 in cancer. Curr Opin Investig Drugs 8: 469-476, 2007.

66. Boidot R, Vegran F, Jacob D, et al: The expression of BIRC5 is correlated with loss of specific chromosomal regions in breast carcinomas. Genes Chromosomes Cancer 47: 299-308, 2008.

67. Huang CL, Liu D, Nakano J, Yokomise H, Ueno M, Kadota K and Wada H: E2F1 overexpression correlates with thymidylate synthase and survivin gene expressions and tumor proliferation in non small-cell lung cancer. Clin Cancer Res 13: 6938-6946, 2007.

68. Zhang X, Zhang J, Wei H and Tian Z: STAT3-decoy oligodeoxynucleotide inhibits the growth of human lung cancer via down-regulating its target genes. Oncol Rep 17: 1377-1382, 2007.

69. Gradilone A, Silvestri I, Scarpa S, et al: Failure of apoptosis and activation on NF- $\mathrm{KB}$ by celecoxib and aspirin in lung cancer cell lines. Oncol Rep 17: 823-828, 2007.

70. Chen YQ, Zhao CL and Li W: Effect of hypoxia-inducible factor- $1 \alpha$ on transcription of survivin in non-small cell lung cancer. J Exp Clin Cancer Res 28: 29, 2009.

71. Krysan K, Merchant FH, Zhu L, et al: COX-2-dependent stabilization of survivin in non-small cell lung cancer. FASEB J 18: 206-208, 2004.

72. Krysan K, Dalwadi H, Sharma S, Pold M and Dubinett S Cyclooxygenase 2-dependent expression of survivin is critical for apoptosis resistance in non-small cell lung cancer. Cancer Res 64: 6359-6362, 2004

73. Yang L, Cao Z, Li F, Post DE, Van Meir EG, Zhong H and Wood WC: Tumor-specific gene expression using the survivin promoter is further increased by hypoxia. Gene Ther 11: 1215-1223, 2004.

74. Caldas H, Jaynes FO, Boyer MW, Hammond S and Altura RA Survivin and granzyme B-induced apoptosis, a novel anticancer therapy. Mol Cancer Ther 5: 693-703, 2006.

75. Hofmann HS, Simm A, Hammer A, Silber RE and Bartling B: Expression of inhibitors of apoptosis (IAP) proteins in non small cell human lung cancer. J Cancer Res Clin Oncol 128 554-560, 2002

76. Holcik M and Korneluk RG: Functional characterization of the $\mathrm{X}$-linked inhibitor of apoptosis (XIAP) internal ribosome entry site element: role of La autoantigen in XIAP translation. Mol Cell Biol 20: 4648-4657, 2000.

77. Holcik M, Gordon BW and Korneluk RG: The internal ribosome entry site-mediated translation of antiapoptotic protein XIAP is modulated by the heterogeneous nuclear ribonucleoproteins $\mathrm{C} 1$ and C2. Mol Cell Biol 23: 280-288, 2003.
78. Gu L, Zhu N, Zhang H, Durden DL, Feng Y and Zhou M: Regulation of XIAP translation and induction by MDM2 following irradiation. Cancer Cell 15: 363-375, 2009.

79. Dan HC, Sun M, Kaneko S, et al: Akt phosphorylation and stabilization of X-linked inhibitor of apoptosis protein (XIAP). J Biol Chem 279: 5405-5412, 2004.

80. Liu WH, Hsiao HW, Tsou WI and Lai MZ: Notch inhibits apoptosis by direct interference with XIAP ubiquitination and degradation. EMBO J 26: 1660-1669, 2007.

81. Hong SW, Kim CJ, Park WS, et al: p34 ${ }^{\text {SEI-1 }}$ inhibits apoptosis through the stabilization of the X-linked inhibitor of apoptosis protein: $\mathrm{p} 34^{\mathrm{SEI}-1}$ as a novel target for anti-breast cancer strategies. Cancer Res 69: 741-746, 2009.

82. Bruno T, Iezzi S, De Nicola F, et al: Che-1 activates XIAP expression in response to DNA damage. Cell Death Differ 15: 515-520, 2008.

83. McNeish IA, Lopes R, Bell SJ, et al: Survivin interacts with Smac/DIABLO in ovarian carcinoma cells but is redundant in Smac-mediated apoptosis. Exp Cell Res 302: 69-82, 2005.

84. Ferreira CG, van der Valk P, Span SW, et al: Expression of $\mathrm{X}$-linked inhibitor of apoptosis as a novel prognostic marker in radically resected non-small cell lung cancer patients. Clin Cancer Res 7: 2468-2474, 2001.

85. Ferreira CG, van der Valk P, Span SW, Jonker JM, Postmus PE, Kruyt FA and Giaccone G: Assessment of IAP (inhibitor of apoptosis) proteins as predictors of response to chemotherapy in advanced non-small-cell lung cancer patients. Ann Oncol 12: 799-805, 2001

86. Petersen SL, Wang L, Yalcin-Chin A, et al: Autocrine TNFa signaling renders human cancer cells susceptible to Smacmimetic-induced apoptosis. Cancer Cell 12: 445-456, 2007.

87. Sun H, Nikolovska-Coleska Z, Yang CY, et al: Design of smallmolecule peptidic and nonpeptidic Smac mimetics. Acc Chem Res 41: 1264-1277, 2008.

88. Bank A, Wang P, Du C, Yu J and Zhang L: Smac mimetics sensitize nonsteroidal anti-inflammatory drug-induced apoptosis by promoting caspase-3-mediated cytochrome c release. Cancer Res 68: 276-284, 2008.

89. Vogler M, Walczak H, Stadel D, et al: Small molecule XIAP inhibitors enhance TRAIL-induced apoptosis and antitumor activity in preclinical models of pancreatic carcinoma. Cancer Res 69: 2425-2434, 2009. 